\title{
Neuroimaging in Multiple Sclerosis
}

\author{
Elisabeth Andreadou \\ Department of Neurology, Athens National and Kapodistrian University, \\ "Aeginition Hospital", Athens \\ Greece
}

\section{Introduction}

Multiple sclerosis (MS) is a chronic disabling autoimmune disorder of the central nervous system histopathologically characterized by inflammation, multifocal demyelination, axonal damage and neuronal loss. Focal intensive demyelination and white matter infiltration by lymphocytes and mononuclear cells are pathological hallmarks of the disease (Ferguson et al., 1997; Lucchinetti et al., 2000).

Complementary to the clinical evaluation, conventional magnetic resonance imaging (cMRI) plays a prominent role for diagnosis and assessment of patients with multiple sclerosis. It provides reliable detection and quantitative estimation of focal white matter lesions in vivo. Modern criteria involve MRI parameters for the diagnosis of MS and for predicting conversion to clinically definite MS in patients who present with a first clinical episode (eg, unilateral optic neuritis) suggestive of disease onset. A diagnosis of multiple sclerosis is based on showing disease dissemination in space and time and excluding other neurological disorders that can clinically and radiologically mimic multiple sclerosis. However, neurological impairment of patients with MS is poorly associated with the lesion load observed on conventional MRI scans. The discrepancy between clinical and conventional MRI findings in MS is explained, at least partially, by the low sensitivity of conventional MRI in the detection of grey-matter involvement and diffuse damage in white matter.

In order to overcome these limitations new uses of conventional MRI methods have evolved and nonconventional MRI techniques have been developed. These advances are expected to help in understanding the underlying disease processes and the accumulation of irreversible disability and therefore are promising tools in studies of disease evolution and clinical trials.

Optical coherence tomography (OCT) -a new, sensitive and non-invasive transpupillary imaging method- is able to provide accurate and quantitative measurements of axonal loss in retina and therefore holds promise as a biomarker for neurodegeneration in MS.

This chapter reviews the use of cMRI techniques to diagnosis and follow-up of patients with MS. It also summarizes the evolving non-conventional MRI and non-invasive optical techniques, which are sensitive to different aspects of MS pathology and are promising to further increase our understanding of disease pathophysiology and the mechanisms accounting for the accumulation of irreversible disability. 


\section{MRI and the diagnosis of multiple sclerosis}

Since multiple sclerosis is a histopathological diagnosis, clinical criteria have been developed for the diagnosis of MS during life. Initial diagnostic criteria were based on clinical features alone to show disease dissemination in space and in time (Schumacher et al., 1965). The introduction of MRI in clinical practice resulted in improved investigation of multiple sclerosis (Young et al., 1981). Paraclinical evidence to support clinical findings in cases of diagnostic uncertainty was first proposed by Poser and colleagues (Poser et al., 1983). Given that MRI is the most sensitive paraclinical test and that comparable MRI abnormalities may be found in a variety of other diseases and in healthy volunteers, criteria have been developed by which MRIs can be classified as suggestive of multiple sclerosis or not (Fazekas et al., 1988; Paty et al., 1988; Barkhof et al., 1997; Tintore et al., 2000).

With the increased availability of MRI scanners and the high sensitivity and ability of MRI to provide evidence for disease dissemination in both space and time, subsequent consensus criteria relied on MRI findings to complement clinical and other paraclinical data for the diagnosis of MS (McDonald et al., 2001). The 2001 McDonald diagnostic criteria for multiple sclerosis included MRI evidence of dissemination in space (DIS) and dissemination in time (DIT), which allowed a diagnosis of multiple sclerosis to be made in patients with clinically isolated syndrome (CIS) (McDonald et al., 2001). The DIS criteria were those developed for brain MRI by Barkhof and colleagues (1997) and Tintore and colleagues (2000), in addition to allowing one spinal-cord lesion to substitute for a brain lesion. Evidence for DIT requires either a gadolinium enhancing lesion after at least 3 months from CIS onset, or a new T2 lesion developing on a scan subsequent to a reference scan obtained at least 3 months after CIS onset (Table 1).

The incorporation of MRI findings to the diagnostic criteria improved the ability to diagnose MS and exclude alternative diagnoses. Apparently MRI started to play a prominent role in establishing a firm and clear diagnosis of multiple sclerosis and predicting conversion to clinically definite MS in patients who present with a first clinical episode (eg, unilateral optic neuritis) suggestive of disease onset. The necessity of early and accurate diagnosis became particularly important with the advent of disease modifying treatments. Subsequently, the McDonald criteria were revised in 2005 by Polman and colleagues, to simplify their use and increase their sensitivity while maintaining their specificity. These revised criteria strengthen the use of spinal cord lesions in MS diagnosis, allowing a spinal cord lesion to substitute for an infratentorial brain lesion. In 2006, new simpler imaging criteria were proposed with similar high specificity for clinically definite MS (CDMS) and increased sensitivity (Swanton et al., 2006), in which DIS requires at least one T2 lesion in at least two of four locations (juxtacortical, periventricular, infratentorial, and spinal-cord) and DIT requires a new $\mathrm{T} 2$ lesion on a follow-up scan. Thereafter, new data and consensus underlined the need to simplify the revised McDonald Criteria in order to improve their comprehension and utility. Accumulating evidence resulted recently in specific recommendations for revisions to the McDonald Criteria. These proposals concerned the use and interpretation of imaging criteria for DIS and DIT and were based on the simplified criteria of Swanton and colleagues (Polman et al., 2011). The 2010 revisions to the McDonald Criteria simplify the diagnostic process with fewer required MRI examinations, allowing a more rapid diagnosis of MS, with preserved or improved specificity and sensitivity 
compared with past Criteria (Table 2). However, even these latest revisions do not address issues of lesion morphology except to emphasize the importance of Gd enhancement and insufficiently deal with lesion location. Distribution and morphology provide important clues to the suspected nature of the detected lesions. In addition, misapplication of the McDonald criteria can lead to misdiagnosis in subjects without relevant clinical symptoms. Therefore, a diagnosis of MS based on incidental findings on MRI alone, should be avoided (Polman et al., 2011).

\begin{tabular}{|c|c|}
\hline Clinical Presentation & Additional Data Needed \\
\hline $\begin{array}{l}\text { - } 2 \text { or more attacks (relapses) } \\
\text { - } 2 \text { or more objective clinical lesions }\end{array}$ & $\begin{array}{l}\text { None; clinical evidence will suffice } \\
\text { (additional evidence desirable but must be } \\
\text { consistent with MS) }\end{array}$ \\
\hline $\begin{array}{l}\text { - } 2 \text { or more attacks } \\
\text { - } \quad 1 \text { objective clinical lesion }\end{array}$ & $\begin{array}{l}\text { Dissemination in space, demonstrated by: } \\
\text { - } \quad \text { MRI } \\
\text { or a positive CSF and } 2 \text { or more MRI lesions } \\
\text { consistent with MS } \\
\text { - } \begin{array}{l}\text { or further clinical attack involving different } \\
\text { site }\end{array}\end{array}$ \\
\hline $\begin{array}{l}\text { - } 1 \text { attack } \\
\text { - } \quad 2 \text { or more objective clinical lesions }\end{array}$ & $\begin{array}{l}\text { Dissemination in time, demonstrated by: } \\
\text { - } \quad \text { MRI } \\
\text { - } \quad \text { or second clinical attack }\end{array}$ \\
\hline $\begin{array}{l}\text { - } 1 \text { attack } \\
\text { - } 1 \text { objective clinical lesion } \\
\text { (monosymptomatic presentation) }\end{array}$ & $\begin{array}{l}\text { Dissemination in space demonstrated by: } \\
\text { - } \quad \text { MRI } \\
\text { or positive CSF and } 2 \text { or more MRI lesions } \\
\text { and } \\
\text { Dissemination in time demonstrated by: } \\
\text { - MRI } \\
\text { - } \quad \text { or second clinical attack }\end{array}$ \\
\hline $\begin{array}{l}\text { Insidious neurological progression } \\
\text { suggestive of MS } \\
\text { (primary progressive MS) }\end{array}$ & 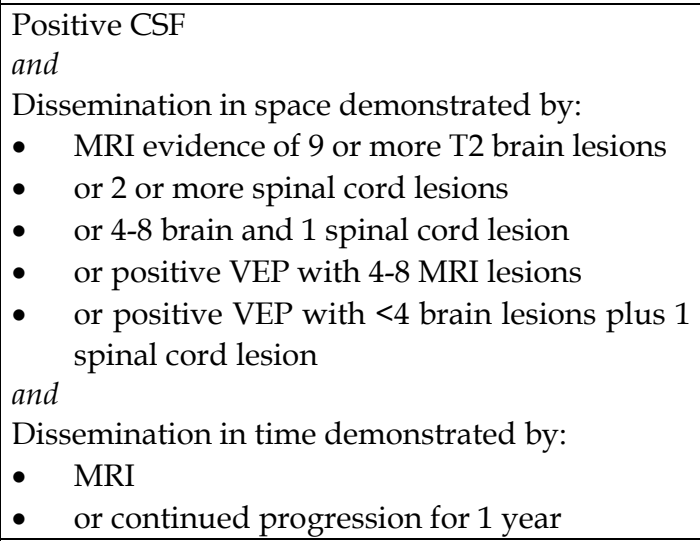 \\
\hline
\end{tabular}

Table 1. 2001 McDonald diagnostic criteria for multiple sclerosis (from McDonald et al., 2001; with permission) 


\begin{tabular}{|c|c|}
\hline Clinical Presentation & Additional Data Needed \\
\hline 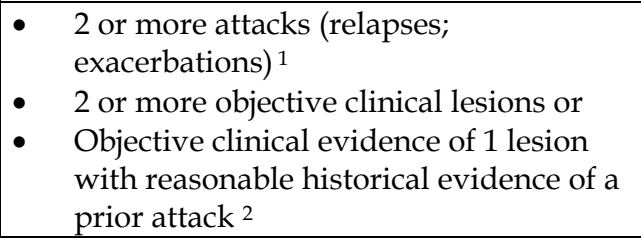 & None $^{3}$ \\
\hline $\begin{array}{ll}- & 2 \text { or more attacks } \\
\text { - } & \text { Objective clinical evidence of } 1 \text { lesion }\end{array}$ & $\begin{array}{l}\text { Dissemination in space, demonstrated by: } \\
\text { - } 1 \text { T2 lesion in at least } 2 \text { of } 4 \text { MS-typical } \\
\text { regions of the CNS (periventricular, } \\
\text { juxtacortical, infratentorial, or spinal } \\
\text { cord) } 4 \\
\text { or } \\
\text { - } \\
\text { Await a further clinical attack } 1 \\
\text { implicating a different CNS site } \\
\end{array}$ \\
\hline $\begin{array}{ll}- & 1 \text { attack }^{1} \\
\text { - } & \text { Objective clinical evidence of } 2 \text { or more } \\
\text { lesions }\end{array}$ & $\begin{array}{l}\text { Dissemination in time, demonstrated by: } \\
\text { - Simultaneous presence of } \\
\text { asymptomatic gadolinium-enhancing } \\
\text { and nonenhancing lesions at any time; } \\
\text { or } \\
\text { - A new T2 and/or gadolinium- } \\
\text { enhancing lesion(s) on follow-up MRI, } \\
\text { irrespective of its timing with reference } \\
\text { to a baseline scan; } \\
\text { or } \\
\text { - }\end{array}$ \\
\hline $\begin{array}{ll}- & 1 \text { attack }^{1} \\
\text { - } & \begin{array}{l}\text { Objective clinical evidence of } 1 \text { lesion } \\
\text { (clinically isolated syndrome) }\end{array}\end{array}$ & $\begin{array}{l}\text { Dissemination in space and time, } \\
\text { demonstrated by: } \\
\text { For DIS: } \\
\text { 1 or more T2 lesion in at least } 2 \text { of } 4 \text { MS- } \\
\text { typical regions of the CNS (periventricular, } \\
\text { juxtacortical, infratentorial, or spinal cord) } 4 \\
\text { or } \\
\text { - Await a second clinical attack }{ }^{1} \\
\text { implicating a different CNS site; } \\
\text { and } \\
\text { For DIT: } \\
\text { - Simultaneous presence of } \\
\text { asymptomatic gadolinium-enhancing } \\
\text { and nonenhancing lesions at any time; } \\
\text { or } \\
\text { - A new T2 and/or gadolinium- } \\
\text { enhancing lesion(s) on follow-up MRI, } \\
\text { irrespective of its timing with reference } \\
\text { to a baseline scan; } \\
\text { or } \\
\text { - Await a second clinical attack }{ }^{1}\end{array}$ \\
\hline
\end{tabular}




\begin{tabular}{|l|l|}
\hline \multicolumn{1}{|c|}{ Clinical Presentation } & \multicolumn{1}{c|}{ Additional Data Needed } \\
\hline & $\begin{array}{l}1 \text { year of disease progression } \\
\text { (retrospectively or prospectively } \\
\text { determined) plus } 2 \text { of } 3 \text { of the following } \\
\text { criteria: } 4 \\
\text { Insidious neurological progression } \\
\text { suggestive of MS (PPMS) }\end{array}$ \\
$\begin{array}{l}\text { Evidence for DIS in the brain based on } \\
1 \text { or more T2 lesions in the MS- } \\
\text { characteristic (periventricular, } \\
\text { juxtacortical, or infratentorial) regions } \\
\text { Evidence for DIS in the spinal cord } \\
\text { based on } 2 \text { or more T2 lesions in the } \\
\text { cord } \\
\text { Positive CSF (isoelectric focusing } \\
\text { evidence of oligoclonal bands and/or } \\
\text { elevated IgG index) }\end{array}$ \\
\hline
\end{tabular}

${ }^{1}$ An attack is defined as patient-reported or objectively observed events typical of an acute inflammatory demyelinating event in the CNS, current or historical, with duration of at least 24 hours, in the absence of fever or infection.

${ }^{2}$ Clinical diagnosis based on objective clinical findings for 2 attacks is most secure. Historical evidence for 1 past attack can include events with symptoms and evolution characteristic for a prior inflammatory demyelinating episode; at least 1 attack, however, must be supported by objective findings.

${ }^{3}$ No additional tests are required. However, it is desirable that any diagnosis of MS be made with access to imaging based on these Criteria.

${ }^{4}$ Gadolinium-enhancing lesions are not required; symptomatic lesions are excluded from consideration in subjects with brainstem or spinal cord syndromes.

Table 2. The 2010 McDonald Criteria for Diagnosis of MS (from Polman et al., 2011; with permission)

\subsection{Characteristic findings on conventional MRI techniques}

Hydrogen protons of water are highly abundant in our body. Conventional MRI measures alterations in tissue water content and dynamics by proton excitation, thus enabling visualization of edema, inflammation, demyelination and axonal damage in MS lesions. Conventional MRI techniques include T2-weighted, fast fluid-attenuated inversion recovery (FLAIR), and T1-weighted imaging with and without gadolinium (Gd) administration.

In routine evaluation of patients with suspected or known MS, the most useful image acquisition clinical protocols for cMRI are axial dual spin-echo or single late echo T2weighted imaging, axial and sagittal FLAIR, and pre- and post-gadolinium (Gd)-enhanced axial spin-echo T1-weighted imaging (Bakshi et al., 2004). On cMRI scans, detected MS lesions are presented as hyperintensities on T2- weighted images, hypointensities on T1weighted images, and Gd-enhancing foci on postcontrast images.

\subsubsection{T2-weighted imaging}

T2-weighted MRI is sensitive in detecting white matter lesions. In T2-weighted images, MS lesions appear as bright areas against a gray or more neutral background; this hyperintesity reflects an increase in water content and thus is not specific for the underlying pathology. 
The T2 hyperintense lesions represent processes ranging from edema and inflammation to demyelination, remyelination, Wallerian degeneration, axonal loss and gliosis (Fillipi \& Agosta, 2009; Markovic-Plese \& McFarland, 2001). Once detected, a lesion typically persists in the T2 hyperintense stage for many years. The techniques that are commonly used for the identification of T2 hyperintense lesions are conventional spin echo, fast spin echo, and fluid-attenuated inversion recovery (FLAIR) (Filippi et al., 2006). FLAIR imaging is a technique that suppresses the CSF signal, being more sensitive to periventricular and cortical/juxtacortical lesions and less sensitive to infratentorial lesions than T2-weighted MRI (Bakshi et al., 2001).

Given the lack of specificity of hyperintensities on T2-weighted MRI, lesion location and morphology plays a prominent role in distinguishing demyelinating lesions from the common and incidental presence of non-specific white-matter abnormalities, microvascular ischemia, or enlarged perivascular spaces (Fig. 1). MS lesions are primarily found in white matter but also in gray matter and usually affect the periventricular regions, corpus callosum, juxtacortical gray-white matter junction in the white matter, and infratentorial brain regions (brain stem, middle cerebellar peduncles and cerebellar white matter in the posterior fossa) (Bakshi et al., 2004; Barkhof et al., 1997). In some cases, direct involvement of the cerebral cortex also may be apparent (Bakshi et al., 2001). Corpus callosum is commonly affected in MS due to the large amount of myelinated fibres it contains. Callosal demyelinating lesions are usually multiple, small, nodular and characteristically involve callosal-septal interface. Infratentorial lesions are considered specific for multiple sclerosis and are typically located at the surface of the pons, the base of the fourth ventricle, and in the intra-axial trigeminal tract. It is important to note however that they can also be found in small-vessel disorder, with characteristic involvement of the central part of the pons (Kwa et al., 1997). Demyelinating lesions are larger (> 3mm) than punctuate non-specific white matter abnormalities associated with migraine and microvascular ischemia. Characteristically, they have an ovoid shape and appear perpendicular to the long axis of the ventricles in the axial plane. These typical MRI findings reflect the histopathological findings in multiple sclerosis. The periventricular lesions, especially in the corpus callosum, and the ovoid abnormalities with extensions (Dawson' fingers) into the adjacent white matter correlate with the perivenular distribution of multiple sclerosis plaques (GeanMarton et al., 1991).

Between $50 \%$ and $90 \%$ of MS patients show hyperintense T2 lesions in the spinal cord, more frequently located in the cervical and the thoracic area (Lycklama et al., 2003; Agosta \& Filippi, 2007). Cord lesions are usually located peripherally, occupy less than one half of the cord cross-sectional area and rarely involve more than two contiguous vertebral segments in length. Acute lesions may be associated with cord swelling. The presence of characteristic spinal cord abnormalities on MRI increases both sensitivity and specificity to the diagnosis of MS (Fillipi \& Agosta, 2009).

In $50-70 \%$ of patients presenting with CIS clinically silent MRI lesions suggestive of MS are found. The extent of T2 lesions on brain MRI in CIS patients can predict the future risk of MS. The majority of CIS patients with T2 abnormalities (56-88\%), develop clinically definite MS (CDMS) after prolonged (7-14 years) follow-up, whereas a minority of those with normal MRI (approximately 20\%) have a risk for conversion to definite MS (Barkoff et al., 1997; Tintoré et al, 2006). Moreover, brain T2 hyperintense lesion load early in the clinical course of MS is also a predictor of long-term disability (Di Filippo et al., 2010). 


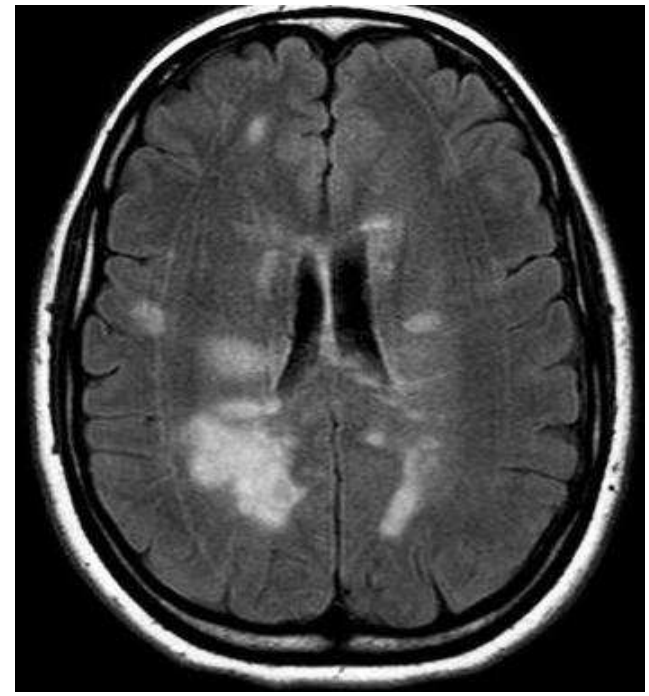

(a) Axial FLAIR image showing typical ovoid periventricular hyperintense MS lesions

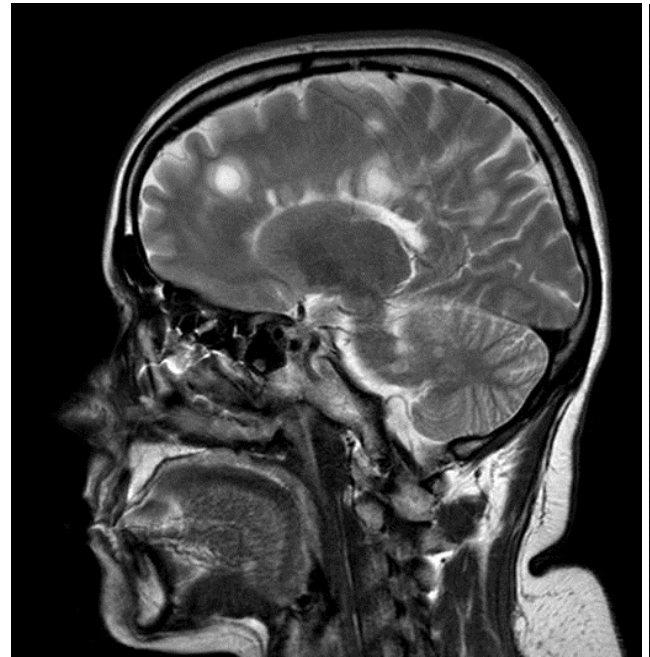

(c) Sagittal T2-weighted image demonstrating lesions in the corpus callosum and periventricular white matter with characteristic extensions (Dawson's fingers)

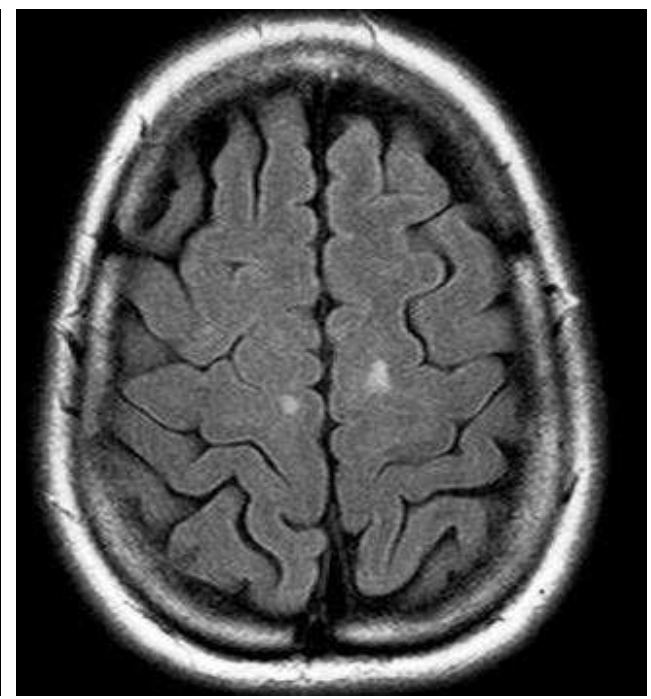

(b) Axial FLAIR scan revealing juxtacortical lesions

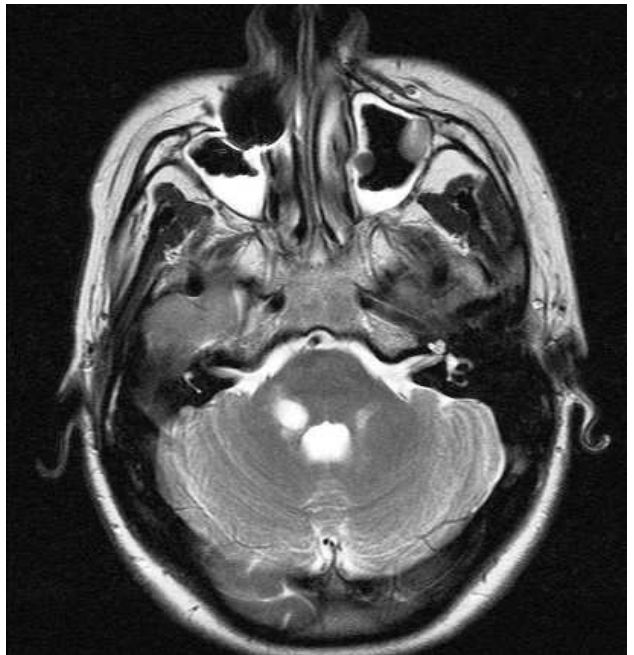

(d) Axial T2 scan showing characteristic infratentorial involvement

Fig. 1. (a-d). Axial and sagittal FLAIR and T2 images showing common sites of MS involvement. 


\subsubsection{T1-weighted imaging}

On noncontrast T1-weighted images (T1-WI), most T2 brain lesions are isointense in white matter; however, some are hypointense (van Walderveen et al., 1998). These hypointense lesions may be acute and reversible within 6 months or chronic (referred to as black holes) (Fig. 2). The acute T1 hypointense lesions are likely to represent oedema and inflammation or demyelination with subsequent remyelination whereas the chronic ones severe demyelination and irreversible axonal loss (Bagnato et al., 2003; Brex et al., 2000; Filippi et al., 2001; Van Walderveen et al., 1998). The percentage of newly formed hypointense lesions that do revert to isointensity varies between 20 and 60\% (van Waesberghe et al., 1998). Larger size of the lesions, longer duration of Gd-enhancement and ring enhancement are associated with the development of persistent T1- hypointense black holes (Mineboo et al., 2005). T1 hypointense lesions correlate better with clinical evolution and disability than T2 lesions and therefore may be a useful biomarker of progressive tissue damage in established MS (Truyen et al., 1996). By contrast to chronic cerebral lesions, chronic spinal cord lesions are isointense on T1-weighted images (Fillipi \& Agosta, 2009).

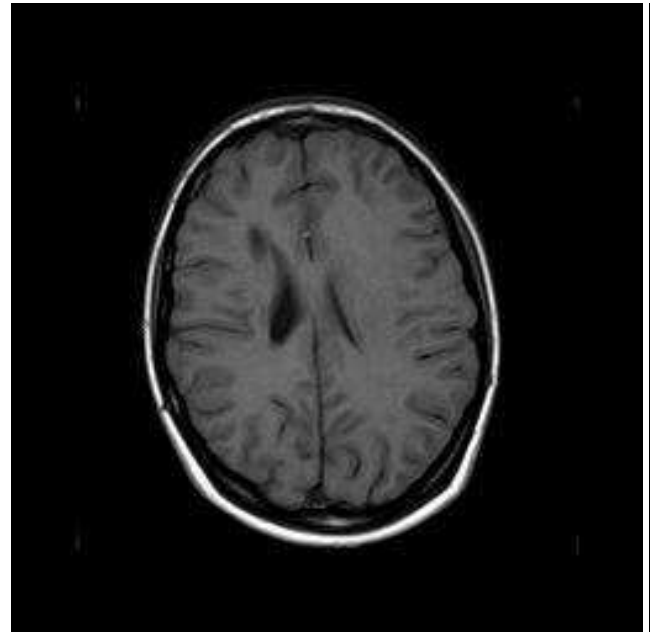

a) Axial T1-weighted noncontrast MRI showing a chronic hypointensity in the right frontal periventricular white matter

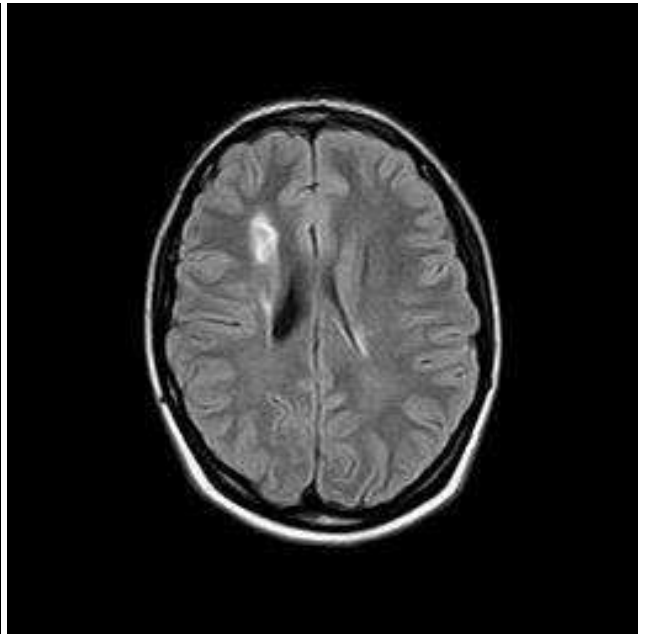

(b) Corresponding hyperintensity on FLAIR scan.

Fig. 2. (a-b) A chronic black hole in a 32-year-old woman with relapsing-remitting MS

\subsubsection{Postcontrast T1-weighted imaging}

On T1-weighted scans, gadolinium injection enables detection of lesions with active inflammation and blood-brain barrier (BBB) disruption, as it is normally excluded from the brain by the BBB. Gd-enhancing lesions on T1-WI typically correspond to areas of high signal intensity on T2-WI and, in some instances, low signal intensity on T1-WI that stem from edema and demyelination (Zivadinov \& Cox, 2007). There are various patterns of gadolinium enhancement in MS lesions that usually persists for 2 - 6 weeks (Cotton et al., 2003): homogeneous, heterogeneous, punctuate, ring, open ring enhancing and tumor-like (Fig. 3). Among them, the incomplete or open-ring morphology (Fig. 3a) is particularly 
characteristic of MS lesions (Masdeu et al., 1996). Compared with homogeneously enhancing plaques, ring-enhancing lesions are larger and have a shorter duration of enhancement (Minneboo et al., 2005). Concentric ring enhancing lesions with central contrast pallor appear in areas of heightened local inflammation (Rovira et al., 1999).

Results of serial MRI studies demonstrate that enhancement usually precedes or accompanies the appearance of most new lesions on T2-WI in all disease subtypes, even in primary-progressive MS (Molyneux et al., 2001). However, Gd- enhancement is more commonly seen in patients with relapsing-remitting (RRMS) than in patients with primary or secondary progressive MS (Thompson et al., 2000) and is considered sensitive to disease activity and predictive of future clinical relapses. Enhancing lesions do not correlate with long-term disability (Kappos et al., 1999), with the exception of ring-enhancing plaques that are usually suggestive of a more aggressive form of MS. Ring-enhancement is associated with severe tissue damage, persisting hypointense T1 lesions and subsequent development of cerebral atrophy (Morgen et al., 2001; Bagnato et al., 2003; Minneboo et al., 2005;). Enhancing lesions are less frequently seen in the cord (Fig. 3b) than in the brain (Filippi \& Agosta, 2009).

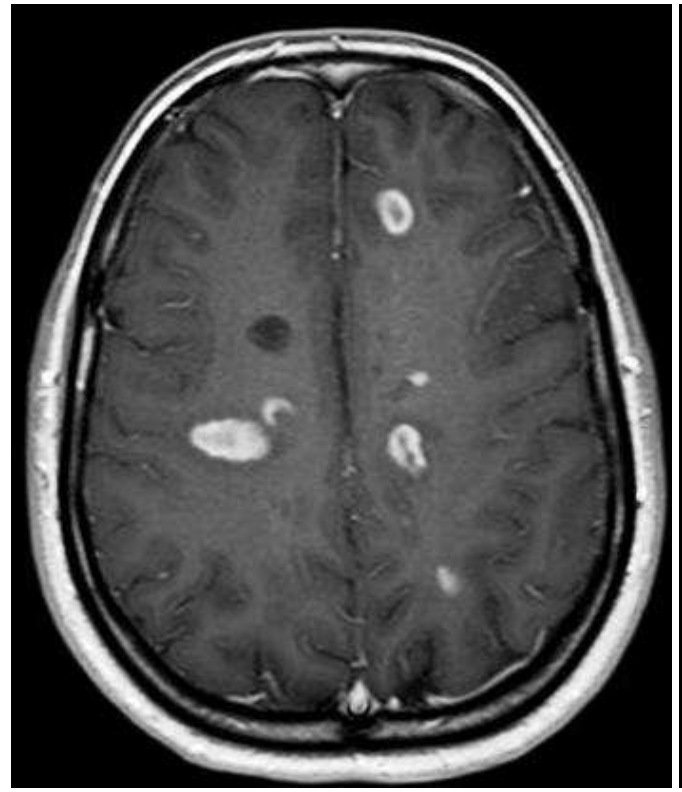

(a) Puctuate, homogeneous, and ring enhancing brain lesions

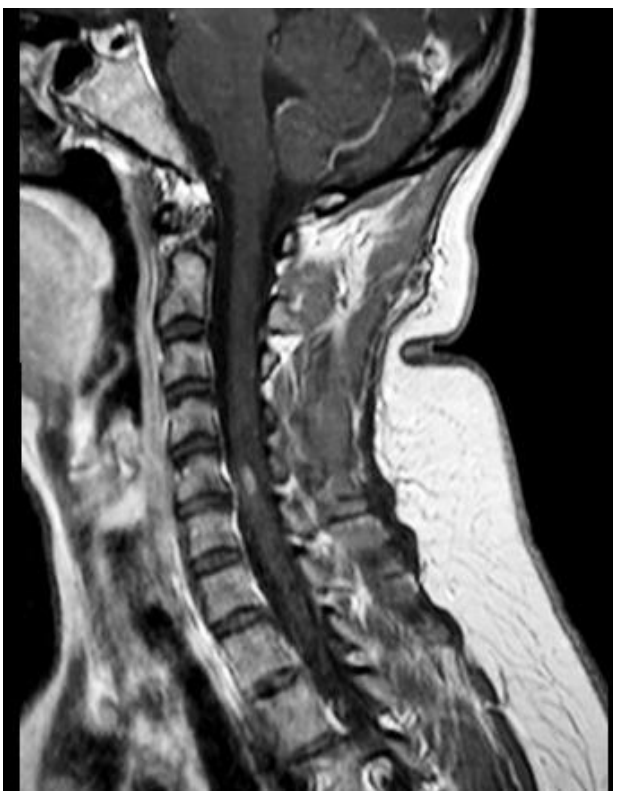

(b) Spinal enhancing lesion

Fig. 3. Characteristic patterns of enhancement on T1-weighted scans

\subsection{Conventional MRI characteristics suggesting alternative diagnoses}

Although existing diagnostic criteria for multiple sclerosis have emphasized that alternative explanation for the clinical presentation must be considered and excluded before a diagnosis of MS can be made, they mainly focus on early diagnosis of patients presenting with a first clinical episode suggestive of MS (e.g., unilateral optic neuritis, internuclear 
ophthalmoplegia, partial myelopathy). Incorporated data from magnetic resonance imaging are used as prognostic for the subsequent development of clinically definite MS, rather than diagnostic (McDonald et al., 2001; Polman et al., 2005, 2011). However, the increased availability of MRI scanners and the sensitivity of this technique in showing asymptomatic lesions of multiple sclerosis, have revealed difficulties in the application of existing MRI criteria, the most common of which is the incidental presence of non-specific white-matter abnormalities on MRI scans of patients who have headache, vertigo or a variety of other common disorders and the inability to differentiate these lesions from those that are typical for MS. Recognition of MRI features that are not suggestive of MS or even suggestive of another disorder is essential, as it underlines the need for extensive evaluation of patients presenting with such abnormalities in order to avoid misdiagnosis.

A set of MRI signs (red flags), which suggest alternative conditions that mimic MS has been defined by the European MAGNIMS group (Charil et al., 2006). It is important to note however that these red flags (Table 3) should be considered in the appropriate clinical context in order to exclude the most common alternatives (Miller et al., 2008).

The distribution of lesions is an important parameter that should be considered in the differential diagnosis of demyelinating lesions. In hypoxic-ischemic diseases lesions follow arterial anatomy, such as borderzone or watershed lesions, lacunes, multifocal basal ganglia lesions and cortical infarcts whereas in multiple sclerosis are perivenular (Enzinger et al., 2006). Moreover, the corpus callosum is not usually involved in hypoxic-ischemic diseases, due to its rich blood supply; on the contrary, this is commonly affected in MS due to the large amount of myelinated fibres it contains, with characteristic involvement of callosalseptal interface (Gean-Marton et al., 1991). Infratentorial lesions are uncommon in smallvessel disorder, but when they occur they are typically located in the central part of the pons (Kwa et al., 1997). The predominance of lesions located at the cortical or subcortical areas, as well as the coexistence of brain infarcts, calcification, or haemorrhages are usually suggestive of systemic immune mediated diseases with CNS involvement, small-vessel vasculitides, or antiphospholipid antibody syndrome (either primary or secondary to systemic immune-mediated diseases). In these disorders, enhancing lesions and T1 black holes are much less common than in multiple sclerosis (Theodoridou \& Settas, 2008). Extensive brainstem and basal ganglia lesions that can be associated with swelling and enhancement in the acute phase and that can shrink or disappear at follow-up may be a manifestation of Behçet's disease (Lee et al., 2001). Bilateral and symmetric white-matter lesions are other important features against the diagnosis of multiple sclerosis. Although adult forms of leucodystrophies, such as adrenoleucodystrophy, metachromatic leucodystrophy, and Krabbe disease may have a MRI pattern resembling that of MS, whitematter lesions tend to be bilateral and symmetric (Barkhof \& Scheltens, 2002). Diffuse and confluent symmetrical T2-weighted hyperintensities in the deep and periventricular white matter with characteristic involvement of the external capsules and temporal poles are considered highly specific for cerebral autosomal dominant arteriopathy with subcortical infarcts and leucoencephalopathy (CADASIL) and may distinguish it from MS (Andreadou et al., 2008; O'Sullivan et al., 2001; Singhal et al., 2005). Moreover, the cortex, corpus callosum and infratentorial regions (except the pons) are rarely affected in CADASIL (Singhal et al., 2005). Furthermore, the presence of multiple microhaemorrhagic foci, which can be seen on gradient-echo images, is another characteristic feature of CADASIL (Dichgans et al., 2002). Another feature pointing against the diagnosis of MS is significant asymmetry of the white-matter abnormalities, which is usually suggestive of ipsilateral carotid disease (Andreadou et al., 2010; Barkhof \& Scheltens, 2002). 


\begin{tabular}{|c|c|}
\hline Brain white matter & Disease \\
\hline Normal & NMO (absent or few lesions), ATM \\
\hline \multicolumn{2}{|l|}{ Lesions } \\
\hline \multicolumn{2}{|l|}{ Morphology } \\
\hline Large lesions & $\begin{array}{l}\text { AMS (sometimes confluent and } \\
\text { perilesional oedema), } \\
\text { BCS (concentric whorls of } \\
\text { alternating rings of enhancement), } \\
\text { PACNS (with mass effect) }\end{array}$ \\
\hline Poorly defined lesion margins & ADEM \\
\hline Absent or rare Dawson fingers & ADEM \\
\hline Absent MRI activity at follow-up & ADEM \\
\hline Isolated lesions with ring enhancement (often complete) & Abscesses \\
\hline Mass effect & Abscesses \\
\hline Large lesions with absent or rare mass effect & PML \\
\hline Multiple bilateral microhaemorrhagic foci & CADASIL, SVD \\
\hline Haemorrhages & PACNS \\
\hline Infarcts & SID, PACNS, SVD \\
\hline \multicolumn{2}{|l|}{ Distribution } \\
\hline Substantially asymmetric distribution of lesions & Ipsilateral carotid disease \\
\hline $\begin{array}{l}\text { Extensive and bilateral periventricular abnormalities in } \\
\text { isolation }\end{array}$ & B12D, ACD \\
\hline Symmetrically distributed lesions & ADEM, AFL \\
\hline Absent or rare corpus callosum and periventricular & \\
\hline lesions & ADEM \\
\hline Frequent sparing of corpus callosum and cerebellum & SVD, CADASIL \\
\hline $\begin{array}{l}\text { Lesions in the centre of corpus callosum, sparing the } \\
\text { periphery }\end{array}$ & Susac's syndrome \\
\hline $\begin{array}{l}\text { T2-hyperintensity of the temporal pole, } \mathrm{U} \text { - fibres at the } \\
\text { vertex, external capsule and insular regions }\end{array}$ & CADASIL \\
\hline $\begin{array}{l}\text { Predominance of lesions at the cortical/subcortical } \\
\text { junction }\end{array}$ & SID \\
\hline Diffuse WM involvement & $\begin{array}{l}\text { NBD, encephalitis (HIVE), SVD, } \\
\text { CADASIL }\end{array}$ \\
\hline Cerebral venous sinus thrombosis & NBD \\
\hline Large and infiltrating brainstem lesions & NBD \\
\hline Pontine lacunar infarcts & CADASIL, SVD \\
\hline $\begin{array}{l}\text { Anterior temporal and inferior frontal lobe involvement, } \\
\text { associated with enhancement or mass effect }\end{array}$ & Encephalitis (HSE) \\
\hline $\begin{array}{l}\text { Multifocal, asymmetrical lesions starting in a } \\
\text { juxtacortical location and progressively enlarging } \\
\text { Pattern of enhancement }\end{array}$ & PML \\
\hline Simultaneous enhancement of all lesions & ADEM, PACNS, sarcoidosis \\
\hline
\end{tabular}




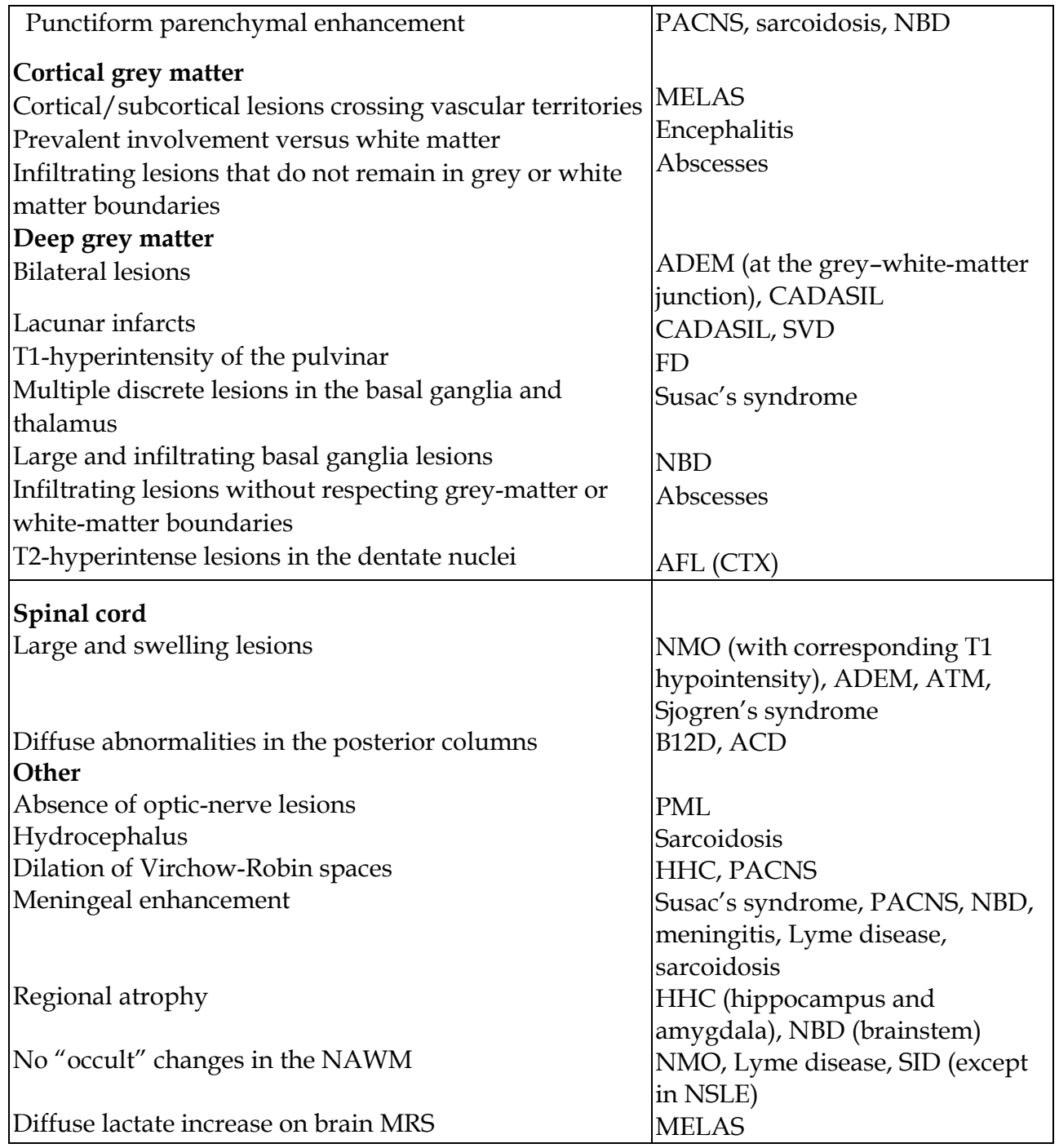

$\mathrm{ACD}=$ acquired copper deficiency. $\mathrm{ADEM}=$ acute disseminated encephalomyelitis. $\mathrm{AFL}=$ adult forms of leucoencephalopathies. AMS=acute multiple sclerosis (Marburg type). ATM=acute transverse myelitis. $\mathrm{B} 12 \mathrm{D}=$ vitamin $\mathrm{B} 12$ deficiency. $\mathrm{BCS}=$ Balo's concentric sclerosis. $\mathrm{CTX}=$ cerebrotendinous $x$ anthomatosis. $\mathrm{FD}=$ Fabry's disease. $\mathrm{HHC}=$ Hyperhomocysteinaemia. HIVE=HIV encephalitis. HSE=herpes simplex encephalitis. MELAS=mitochondrial encephalopathy with lactic acidosis and stroke-like episodes. MRS=magnetic-resonance spectroscopy. NAWM=normal-appearing white matter. NBD=Behçet's disease with CNS involvement. $\mathrm{NMO}=$ neuromyelitis optica. $\mathrm{NSLE}=$ neuropsychiatric systemic lupus erythematosus. PACNS=primary angiitis of the CNS. PML=progressive multifocal leucoencephalopathy. SID=systemic immune-mediated diseases. SVD=small-vessel disease.

Table 3. MRI characteristics suggestive of alternative conditions that mimic MS (adapted from Charil et al., 2006; with permission). 
By contrast to MS where MRI-detectable spinal cord lesions can be found in the majority of patients with established disease (Lycklama et al., 2003; Agosta and Filippi, 2007), spinal cord abnormalities are not observed in patients with hypoxic-ischemic disease and are rarely reported in other immune-mediated disorders (Bot et al, 2002), and progressive multifocal leucoencephalopathy (Yousry et al., 2006). Another characteristic pointing against the diagnosis of MS is the complete disappearance of spinal cord lesions in systemic immune-mediated diseases after steroid or immunosuppressive treatment (Rovaris et al., 2000). Moreover, incidental spinal cord hyperintense foci do not occur with ageing (Lycklama et al., 2003). Therefore, cord MRI is helpful in patients with normal or equivocal brain MRI and in those more than 50 years old (Agosta \& Filippi, 2007). Longitudinally extensive spinal cord involvement (usually three or more segments), affecting primarily the central part of the spinal cord on axial sections, is typically seen in neuromyelitis optica. Moreover, NMO myelopathy is often associated with swelling and T1 hypointensity in the acute and chronic stages (de Seze et al., 2002; Wingerchuk et al., 2007).

The pattern of enhancement is another useful distinctive characteristic. Simultaneous enhancement of multiple white-matter lesions is usually observed in neurosarcoidosis and primary angiitis of the CNS (PACNS). Moreover, meningeal enhancement should raise the suspicion of PACNS, neurosarcoidosis or neuroBehçet's disease (Campi et al., 2001; Zajicek et al., 1999).

It is important to note that when these MRI features 'not suggestive' of multiple sclerosis are used along with the existing MS diagnostic criteria, they minimize the chance of false positive diagnoses and facilitate the correct diagnosis of other disorders. Therefore, it is suggested to be taken into account in the diagnostic work-up of patients suspected of having MS. In the presence of at least one MRI 'red flag', appropriate additional tests should be performed. However, in cases of equivocal findings, follow-up with repeated imaging will be needed to establish a firm diagnosis (Charil et al., 2006)

\section{MRI and disease progression}

Recognition of the neurodegenerative aspects of MS has rendered the development of techniques to measure disease progression essential. Since conventional MRI is sensitive in detecting disease activity, it has routinely been used to ameliorate not only the accuracy of multiple sclerosis diagnosis but also the prognosis. Conventional MRI assessment of lesions on non-contrast T1-weighted and T2-weighted scans, and on gadolinium-enhanced T1weighted images is now routinely used to monitor the disease course and detect therapeutic effects (Zivadinov \& Leist, 2005). However, measures like the lesion volume and the number of gadolinium-enhancing and T2 lesions, are weakly associated with the clinical status and have insufficient sensitivity and specificity to reveal the extent of histopathological changes occurring in MS. Persistent T1 hypointense lesions can predict development of disability better than the previously mentioned lesion-based MRI measures (Zivadinov \& Leist, 2005) as they are mainly associated with more advanced pathological processes of the disease, i.e. axonal loss, Wallerian degeneration and gliotic changes (Bakshi et al., 2004; Stevenson et al., 2004). Moreover, brain and spinal cord atrophy have been shown to be powerful predictors of clinical impairment and disease progression. Additionally, newer nonconventional MRI techniques that become increasingly available hold significant promise to improve monitoring of MS. Accumulating evidence suggests that metrics derived from non-cMRI techniques correlate better with disability compared to conventional measures. 


\subsection{Detection of subclinical disease activity}

Conventional MRI can be used as a valuable tool for the assessment of disease progression, as it provides objective and sensitive measures of MS activity. In patients with RRMS and SPMS, disease activity is detected 5-10 times more frequently on cMRI scans than with clinical assessment of relapses (Filippi \& Agosta, 2010). Despite the sensitivity of T2weighted images to reveal disease activity and lesions over time (Molyneux et al., 1998), no significant correlation between MRI findings and clinical progression has been demonstrated, except in patients with very early disease (Rovaris et al., 2003). Indeed, both brain T2 hyperintense lesion load early in the clinical course and early progression of T2 burden of MS have been associated with the development of long-term disability (Brex et al., 2002). However, T2 lesion load measurement is not appropriate for the assessment of the advanced stages of the disease (Li et al., 2006). Although differences in T2 lesion load among different MS phenotypes have been consistently reported, being higher in SPMS in comparison to benign MS, RRMS, and PPMS, no significant relationship between T2 lesion load and disability has been demonstrated (Filippi \& Agosta, 2010).

Gd enhancement occurs in almost all new lesions in patients with RRMS or SPMS and can be sometimes detected even before the onset of clinical symptoms (Filippi \& Agosta, 2010). The number of enhancing lesions increases shortly before and during clinical relapses and predicts subsequent MRI activity (Molyneux et al., 1998, Kappos et al., 1999). The burden of MRI activity has been shown to be associated with the subtype of the disease, being higher in RRMS and SPMS in comparison with PPMS and BMS (Kappos et al., 1999). Moreover, patients with SPMS and severe disability show a lower incidence of enhancing lesions when compared to those with mildly disabling RRMS (Filippi et al., 1997). However, a moderate correlation has been demonstrated between the degree of clinical disability and the mean frequency of enhancing lesions in patients with RRMS and SPMS (Filippi \& Agosta, 2010).

T1 black holes and CNS atrophy are useful markers of progressive tissue damage and clinical evolution in established MS. In patients with either RRMS or SPMS, the increase in T1 lesion volume (LV) over time correlates significantly with progressive cerebral atrophy and the change in EDSS score (Sailer et al., 2001; Truyen et al., 1996). Moreover, in patients with CIS, baseline T1 hypointense lesion number and volume are strong predictors of the severity of executive dysfunction (Summers et al., 2008).

\subsection{Detection of brain and spinal cord atrophy}

Since the initial MRI studies in MS, marked atrophy of the brain has been found to be an important feature of the advanced stages of the disease (Filippi \& Agosta, 2010). Subsequently, it was recognised as an early phenomenon that progresses over the disease course. Thus, conventional MRI has been used to measure atrophy of the brain tissue, whole or segmented in white matter (WM) and gray matter (GM). Cerebral volume loss is associated with changes in normal appearing white matter and grey matter (Ge et al., 2000; Horakova et al., 2009). It occurs in all MS subtypes (even in CIS) with a rate of $0.5-1 \%$ per year and is closely related to disability (Anderson et al., 2006; Bermel \& Bakshi, 2006). Moreover, brain atrophy develops in different structures in the different clinical phenotypes of the disease: ventricular enlargement is predominant in RRMS, whereas cortical atrophy is more pronounced in the progressive forms of the disease (Pagani et al., 2005). The most atrophic cortical regions have been consistently found to be the frontal, temporal and parietal lobes (Filippi \& Agosta, 2010). GM atrophy rate has been found to increase with 
disease progression, whereas WM atrophy rate has been reported to remain constant (Fisher et al., 2008). Atrophy of the deep gray matter has been also observed in MS, especially in the posterior basal ganglia and the thalamic regions (Bermel \& Bakshi, 2006; Carone et al., 2006; Filippi \& Agosta, 2010; Henry et al., 2008). Measurement of atrophy in selected pathways, such as the corpus callosum and the corticospinal tract, may also improve the in vivo monitoring of MS progression (Martola et al., 2007). In addition, spinal cord atrophy, more pronounced in the progressive forms of MS, has been reported (Rovaris et al., 2001). It should be mentioned, however, that reduction of the cervical cord size can be observed in the early stages of MS (Brex et al., 2001). CNS atrophy reflects the destructive component of the MS disease process and contributes to irreversible neurological impairment.

Recent advances in volumetric MRI with the use of parallel imaging techniques may improve the use of atrophy metrics as outcome measures in clinical trials of MS therapies. It should be mentioned however, that the anti-inflammatory effect of MS treatments can reduce brain volume (a phenomenon called pseudoatrophy effect), and consequently affect atrophy measurements (Zivadinov et al., 2008). Advances in neuroimaging may help separate true atrophy from pseudoatrophy with the use of methods that can distinguish axonal loss from transient changes in water content.

\subsection{MRI in disease management and evaluation of treatment outcomes}

Since MRI provides information essential in monitoring disease activity and severity of multiple sclerosis, it is a critical component of disease management. In addition to the relapse rate and progression on EDSS, MRI variables play an essential role in determining the short and long-term effects of MS treatments, since the approval of the first therapy for MS by the Food and Drug Administration in 1993 (Rovaris, 2008; Bates, 2011; Freedman, 2011). Short-term and long-term clinical trial results have indicated that currently available disease-modifying therapies (DMTs) are effective in reducing MRI disease activity (Bates, 2011; Freedman, 2011). Moreover, reduction in MRI-detected lesion burden is used as supportive to the clinical findings to show reduction in disease activity. Brain MRI activity is determined as the number of new or enlarging T2-hyperintense lesions and Gd-enhancing lesions, whereas the MRI burden of the disease includes the T2-lesion volume and the T1hypointense LV.

Accumulating evidence suggests that MRI-derived metrics could be used to define treatment options and strategies in individual patients with MS (Beck et al., 2002; Rudick et al., 2004). In RRMS, the accumulation of two or more new T2-hyperintense lesions during a two-year period has been demonstrated to predict poor treatment response more reliably than the persistence of clinical relapses and the presence of enhancing lesions (Rudick et al., 2004). In CIS, the subgroup of patients with enhancing lesions at baseline showed a trend for greater treatment benefit than patients without (Beck et al., 2002). However, only the integration of clinical and MRI data can be considered a reliable approach for the work-up of patients receiving disease-modifying treatments.

Recently, clinical trials have incorporated cerebral volume measurement to determine the efficacy of novel treatments (Bermel \& Bakshi, 2006). However, the current inability to separate true atrophy from pseudoatrophy limits the use of atrophy measures at present. Advances in MRI technology might contribute to a better correlation between clinical and MRI findings, and thus provide relevant information to improve prognosis and predict therapeutic response. 


\section{Nonconventional MRI techniques}

Conventional MRI is unable to disclose the extent of the damage because of its limited sensitivity to structural changes outside the focal lesions and its lack of specificity to the heterogeneous features of the disease. The hyperintense lesions on T2-weighted images represent nonspecific tissue alterations as they reflect changes in water content caused by a variety of processes including edema, inflammation, demyelination, remyelination, Wallerian degeneration, gliosis and axonal loss. Furthermore, neurological impairment of patients with MS is poorly associated with the lesion load observed on conventional MRI scans (Filippi \& Agosta, 2010). During the past decade, other nonconventional MRI techniques-including proton MR spectroscopy, magnetization transfer MRI, diffusion tensor MRI, double inversion recovery sequences, high-field and ultrahigh-field MR imaging, techniques employing cellular MR contrast agents, and functional MRI-have been developed to overcome these limitations, improve the sensitivity and specificity in the detection of MS lesions and characterize and quantify the heterogeneous pathological substrates of the disease. Issues encountered in emerging clinical application of these methods will be addressed.

\subsection{Magnetic resonance spectroscopy}

Conventional MRI describes the physical characteristics of a region of tissue relative to surrounding regions by measuring alterations in tissue water content and dynamics by proton excitation. Proton MR Spectroscopy ( $\left.{ }^{1} \mathrm{H}-\mathrm{MRS}\right)$ is a non invasive method that depicts the chemical properties of a region of brain tissue by investigating other proton-containing cellular metabolites. It provides information on tissue metabolism and function of a selected brain area volume relative to surrounding regions. Therefore it could be used to study biochemical changes occurring in lesions and normal appearing white matter over the course of MS (De Stefano et al., 2007). ${ }^{1} \mathrm{H}-\mathrm{MRS}$ could also be used as a diagnostic tool, although it has not yet moved to clinical practice.

Various compounds can be detected using ${ }^{1} \mathrm{H}-\mathrm{MRS}$. At long echo times four major resonance peaks are revealed from (a) choline-containing phospholipids (Cho), (b) creatine and phospho- creatine (Cr), (c) N-acetyl-aspartate (NAA), and (d) lactate (Lac) methylgroup. NAA, normally present in axons and neurons, reflects neuronal/axonal integrity and therefore appears to be a sensitive biomarker of disease progression (Narayana, 2005). A decline in NAA levels in MS, with correlation with disability, has been shown in several studies. Reduced NAA was observed in lesions, cortical GM and NAWM in early RRMS (Kapeller et al., 2001; Chard et al., 2002). Decrease in NAA levels in chronic WM lesions has been reported in RRMS, SP and PPMS (Davie et al., 1997). Moreover, chronic lesions have higher NAA signal intensities in patients with BMS than those in patients with SPMS, indicating a more efficient tissue integrity recovery in patients with less severe disability (De Stefano et al., 2007). Transient changes in NAA levels in acute MS plaques have been also reported (Narayama et al, 1998). Decreases in NAA concentrations are also known to occur in the NAWM of MS patients (Caramanos et al., 2005). Furthermore, significant reduction in whole-brain NAA levels was found, more pronounced in older than younger patients (Gonen et al., 2000).

Cho and Lac reflect cell membrane metabolism. Increases in these metabolites are considered as chemical correlates of acute inflammatory or demyelinating changes. Indeed, increases in Cho and Lac resonance intensities have been found in acute MS lesions (Davie 
et al., 1994; De Stefano et al., 1995). In large, acute demyelinating lesions, decreases of $\mathrm{Cr}$ have also been seen (De Stefano et al., 1995).

${ }^{1} \mathrm{H}-\mathrm{MRS}$ studies with shorter echo times can detect additional metabolites, such as lipids and myoinositol (mI), which are also regarded as markers of progressing myelin damage. Increase of levels of myoinositol, which is mainly localised in astrocytes, has been shown in early MS (Capeller et al., 2001; De Stefano et al., 1995) and also in chronic lesions, indicating neuronal injury and ongoing astrogliosis (Srinivasan et al., 2005). Amino acids acting as neurotransmitters, such as glutamate, glutamine, and GABA ( $\gamma$-aminobutyric acid), can also be measured. Glutamate levels were found to be increased in acute lesions (Srinivasan et al., 2005). A reduced concentration of glutamate and glutamine in the cortical GM of patients with PPMS has been found (Sastre-Garriga et al., 2005), which was significantly correlated with the EDSS score. Recently, the concentration of glutathione, a marker of oxidative status, was measured by ${ }^{1} \mathrm{H}-\mathrm{MRS}$ at $7.0 \mathrm{~T}$ and was found decreased in the NAWM and gray matter of MS patients compared to healthy controls (Srinivasan et al., 2010).

MRS may provide insight into MS pathogenesis, evaluate the severity of MS and follow disease evolution and therefore is becoming a useful tool in the understanding of the disease. Moreover, MRS measures of brain metabolites seem to be better predictors of clinical disability than is conventional MRI.

\subsection{Magnetization transfer imaging}

Magnetization transfer (MT) is a physical phenomenon in which protons of two or more environments with different magnetic resonance properties exchange magnetization. MT MRI measures quantitatively the continuous exchange of magnetization in the brain tissue between macromolecular bound protons (i.e. protons associated with myelin, cell membranes and proteins) and protons in adjacent free water molecules, thus allowing the calculation of an index, the MT ratio (MTR). Diminution of this index denotes a decreased capacity of the bound protons to exchange magnetization with the surrounding "free" water (Filippi \& Agosta, 2007). The reduction of MTR values in focal lesions is considered as a marker of the extent of tissue damage, primarily associated with demyelination (Schmierer et al., 2004; van Buchem et al., 1996). The relative specificity of MTR to myelin density has been demonstrated by post-mortem imaging and histopathological studies that did not reveal any significant association with axonal density or gliosis (Schmierer et al., 2004).

Voxel-based analysis of MTR changes can provide indirect information about demyelination and remyelination in MS lesions (Chen et al., 2007). Changes of MTR of individual lesion voxels, as well as the mean normalized MTR over all lesion voxels during and after contrast enhancement have been reported (Chen et al., 2008). The mean normalized MTR of Gdenhancing lesions was significantly decreased at the time of lesion enhancement, partially recovered over the subsequent four months, and then appeared to stabilize. Moreover, enhancing lesions were found to have different MTR values, according to their size, pattern, and duration of enhancement. Specifically, MTR was lower in ring-enhancing lesions than in homogeneously enhancing lesions (Silver et al., 1998) and in lesions with longer duration of enhancement (Filippi et al., 1998a), suggesting more severe demyelination. Furthermore, evolution of the mean normalized MTR of individual lesions shows considerable heterogeneity ranging from partial recovery or stability that suggest remyelination, to decline over time that suggests ongoing demyelination (Chen et al., 2008). 
In addition to increased specificity, MTI may also offer increased sensitivity for studies of MS. Focal changes in magnetization transfer were reported to precede the appearance of gadolinium-enhancing lesions (Filippi et al., 1998b). Moreover, microscopic damage in normal-appearing brain tissues was shown on MTI before the development of T2 lesions on cMRI scans (Laule et al., 2003).

Decreased MTR has also been found in normal appearing brain tissue (NABT), in both gray (Ge et al., 2001; Dehmeshki et al., 2003) and white matter (Santos et al., 2002), of patients with established MS. These abnormalities are more pronounced in patients with the progressive forms of MS and tend to worsen over time (Filippi \& Rocca, 2007). Moreover, reduced NABT MTR has been found in patients at presentation with CIS, with significant prognostic value for the subsequent evolution to clinically definite MS (Miller et al., 2005). NAWM and NAGM MTR abnormalities have been found to correlate with clinical disability (Ge et al., 2001; Santos et al., 2002) and cognitive impairment (Ranjeva et al., 2005).

MTI metrics have several limitations that include lack of specificity to the various MS pathological substrates and lack of standard magnetisation transfer data acquisition protocols across different scanners (Horsfield et al., 2003). Improvement of the quantification and specificity of MTI with the use of new analysis methods (Chen et al., 2008) may render this technique a reliable tool not only for studies of disease evolution, but also for diagnostic purposes in every day clinical practice.

\subsection{Diffusion weighted and diffusion tensor imaging}

Diffusion weighted (DWI) and diffusion tensor imaging (DTI) provide information about the tissue fibers by measuring the motion of tissue water molecules in vivo (Rovaris et al., 2005). The mobility of water molecules is diminished in highly organized tissue, like white and gray matter, and consequently, the apparent diffusion coefficient (ADC) is lower in those tissues than in free water. Pathological processes that alter tissue organization can result in abnormal water motion, thus modifying ADC values. Tissue damage in MS, mainly demyelination and axonal degeneration, results in abnormal water motion, and therefore in alteration of the ADC values. Diffusion abnormalities may precede Gd-enhancement in hyperacute MS lesions.

Diffusion tensor imaging (DTI) is a valuable technique based on the fact that diffusion of water molecules within white matter is much greater along the fibres than across them. The diffusion tensor is a mathematical description of the magnitude and predominant direction of water molecules movement (anisotropy) in the three-dimensional space. As the diffusion ellipsoid provides a description of the diffusion tensor, the individual components of the diffusion ellipsoid (called eigenvalues) can also be assessed separately. These components are the longitudinal or axial diffusivity (LD or $\mathrm{AD}$ ), which is the principal eigenvalue of the $\mathrm{DT}$, and the transverse or radial diffusivity (TD or RD) that is the average of the second and third eigenvalues of the DT. Quantitative DTI parameters, such as the fractional anisotropy (FA), which is a normalized measure of the degree of anisotropy, the mean diffusivity (MD), that is the averaged diffusion for detecting WM alterations, and the longitudinal and transverse diffusivities of the diffusion tensor are considered valuable tools in the assessment of focal and widespread white matter tissue damage in patients with MS. FA was found to be decreased (Werring et al., 1999) whereas MD was consistently shown to be increased in MS plaques as well as in normal appearing white matter of MS patients (Lowe 
et al., 2006). However, FA values have been found to be increased in intracortical MS lesions, possibly reflecting intralesional loss of dendrites and activation of microglia (Poonawalla et al., 2008). Transverse diffusivity, which refers to the diffusion across fibers, is believed to be a specific marker for axonal loss and demyelination associated with MS (Oh et al., 2004; Lowe et al., 2006; Henry et al., 2003). Relative increase of TD has been shown in MS, correlating with demyelination and axonal loss (Song et al., 2005). This finding suggests that fragmented or missing myelin permits greater diffusion of water molecules across fibers. Moreover, quantitative variables derived from DTI were found to correlate with clinical disability (Filippi \& Agosta, 2010).

Fiber tractography is a diffusion technique based on the directional movement of water, which allows the generation of non-invasive three-dimensional images of white matter fiber tracts. It is a promising method for in vivo segmentation of the major WM tract fiber bundles in the brain (Mori et al., 2002). In MS patients, DT MRI tractography can be used to segment clinically eloquent WM pathways, such as the corticospinal tracts, the corpus callosum, and the optic radiations and holds promise in enabling visualization and quantification of the degree of axonal loss and demyelination in vivo. However, the application of DTI tractography in MS is limited by the presence of both focal and diffuse alterations of tissue structure, which cause a decrease in anisotropy and consequently an increase in uncertainty of the primary eigenvector of the DT (Pagani et al., 2007). Using DT MRI tractography, a study in patients with optic neuritis showed reduced connectivity values in both left and right optic radiations compared with controls, possibly attributed to trans-synaptic degeneration secondary to optic nerve damage (Ciccarelli et al., 2005). DT MRI tractography has been also used to identify NAWM fibers at risk for degeneration, when they intersect T2-visible lesions (Simon et al., 2006). A recent study found increased interthalamic connectivity in patients with early MS as measured by DTI and tractography when compared with control subjects, suggesting a possible reactive structural reorganization of the fiber tracts within the thalami (Tovar-Moll et al., 2009).

Technical improvements of tensor models may allow better description of water diffusion in more complex architectures such as those with crossing fiber tracts, better segmentation of fiber bundles and better understanding of the relationship between tissue structure and function.

\subsection{Double inversion recovery imaging}

Double inversion recovery (DIR - i.e. two inversion times are used to suppress the signal from both white matter and cerebrospinal fluid) is a novel imaging method that has markedly improved the sensitivity of MRI to detect cortical lesions in vivo (Geurts et al., 2005). Cortical demyelination is an important part of the disease process, especially in more advanced stages (Kutzelnigg et al., 2005), and may contribute to the accumulation of irreversible disability in MS (Calabrese et al., 2009a,b; Calabrese et al., 2010; Roosendaal et al., 2009). Despite improvement, at present only a small number of cortical gray matter lesions can be detected with this technique, compared with pathological studies (Calabrese et al., 2007; Geurts et al., 2008).

Cortical lesions have been detected in all the major MS clinical phenotypes, including patients with CIS suggestive of MS (Calabrese et al., 2009a, b). Remarkably, cortical lesions are more frequently seen in patients with secondary progressive MS than in those with CIS 
or RRMS. Moreover, patients with early RRMS have a greater number of lesions than patients with benign MS (Calabrese et al., 2009a). Longitudinal studies have shown that new cortical lesions continue to form in patients with early RRMS (Calabrese et al., 2009a), and in those with the progressive disease phenotypes over 1 to 2-year periods of follow-up (Calabrese et al., 2009b; Roosendaal et al., 2009). Cortical lesion burden has been associated with progression of disability over the subsequent 2 to 3 years in patients with different disease phenotypes (Calabrese et al., 2009b), as well as with the severity of cognitive impairment in patients with RRMS (Roosendaal et al., 2009).

DIR sequences at $1.5 \mathrm{~T}$ have not been established as yet into the clinical routine probably because of the relatively low signal-to-noise ratio values due to the application of two inversion pulses, longer acquisition times and higher propensity of artefacts. DIR applications at higher magnetic field strengths may overcome these major problems (Wattjes \& Barkhof, 2009).

\subsection{Functional MRI}

Functional MRI (fMRI) is a non-invasive neuroimaging method that enables visualisation not only of the detailed anatomy but also of brain function. It is used to identify changes in brain activation in response to various stimuli and in the resting state. The fMRI signal reflects blood oxygenation level-dependent (BOLD) alterations associated with activation of neural tissue. This mechanism permits the detection of changes in the relationship between blood flow and local oxygen consumption. Upon initiating a task, neural activity in the involved brain region results in increased blood flow and consequently in increased total blood oxygen content (Logothetis et al., 2001; Ogawa et al., 1990). The increased blood oxygen produces an increase in the MRI signal, thus allowing demonstration of abnormal patterns of brain activation caused by tissue injury.

fMRI is not used clinically for the diagnosis of MS; rather it is used to provide insight into disease progression. The most common finding in fMRI studies is increased extent or strength of activation of functional tissue in MS patients compared with controls, implying compensatory processes or reorganization of neuronal activation (Lee et al., 2000; Penner et al., 2003; Reddy et al., 2000; Rocca et al., 2005). At the initial stages of the disease, an increased recruitment of the areas normally involved in the performance of a given task, such as the primary sensorimotor cortex and the supplementary motor area is shown (Rocca et al., 2003). At later stages, bilateral activation of these regions is first observed, followed by a widespread recruitment of additional areas, which are usually recruited by healthy subjects in the performance of more complex or novel tasks (Rocca et al., 2005). Similarly, fMRI studies investigating various cognitive domains in MS patients have shown altered patterns of cortical activation (Audoin et al., 2003; Staffen et al., 2002; Hillary et al., 2003; Li et al., 2004; Cader et al., 2006). Moreover a relationship between cortical activation and fatigue has been shown in several studies suggesting that the underlying mechanism of this common but poorly understood symptom may be the deficiency of neuronal compensation (Filippi et al., 2002; White et al., 2009).

Functional connectivity MRI (resting-state fMRI) is a newer fMRI method that measures low frequency oscillations $(0.01-0.1 \mathrm{~Hz})$ in BOLD signals across the whole brain during rest, thus enabling measurement of functional interactions between brain regions (Cordes et al., 2000). Since it studies the strength of network between anatomically separated brain regions, it is 
considered a promising method to explore disconnectivity effects in MS (van den Heuvel \&, Hulshoff Pol, 2010). Indeed, decreased levels of functional connectivity of regions of the primary motor network have been reported in patients with MS (Lowe et al., 2008).

Since studies with fMRI have demonstrated consistently functional cortical changes in all MS subtypes, this method can be used to assess the role of brain plasticity and cortical adaptive changes in limiting the clinical manifestations of demyelination and tissue loss in MS and therefore explain the discrepancy between clinical and cMRI findings.

\subsection{High and ultrahigh-field MRI}

Magnet field strengths higher than 1.5 Tesla (T) improve image resolution, signal-to-noise ratio and chemical shift. Therefore application of high-field MRI on conventional and quantitative MRI methods offers advantages on brain imaging in MS, as it may give new insights into the microstructural damage and functional reorganization (Wattjes \& Barkhof, 2009). In patients with established MS, high-field MRI has resulted in a higher detection rate of T2 (Wattjes et al., 2009) and gadolinium-enhancing brain (Sicotte et al., 2006) but not spinal cord (Stankiewicz et al., 2009) lesions at 3.0T compared with 1.5T. In CIS patients, however, 3.0T imaging did not substantially affect evidence for disease dissemination in space (Wattjes et al., 2008).

Ultrahigh-field MRI (referred to as imaging at field strength of 7 Tesla or more) provides improved brain lesion load quantification and characterization of the pathological features of MS lesions. It is also likely that detection of GM and spinal cord abnormalities could be improved by ultrahigh-field MRI (Kangarlu et al., 2007).

Both high-field and ultra-high field MRI can improve 1H-MRS by providing better quantification of metabolites in lesions and the normal-appearing brain tissue (white and gray matter) (Srinivasan et al., 2004, 2005, 2009). Magnetisation transfer MRI, diffusion tensor MRI, and fMRI studies in MS may also benefit from higher field strengths (Bakshi et al., 2008; Wattjes \& Barkhof, 2009). Indeed, subtle damage in the NAWM and NAGM Ceccarelli ea al., 2007), as well as diffuse microscopic damage in the absence of macroscopic MS lesions in the thalamus and basal ganglia has been detected by the use of high-field MRI (Tovar-Moll et al., 2009). Finally, higher field MRI might be important for studying iron deposition in the grey matter of patients with MS, which has been postulated to contribute to neurotoxicity (Stankiewicz et al., 2007).

\subsection{New MR contrast agents}

Conventional MRI allows follow-up of lesion development in time and space. Although in clinical practice the number of hyperintense lesions on T2-weighted MRI is considered as a biomarker of disease activity in MS, they represent nonspecific tissue alterations. Commonly, the identification of gadolinium-DTPA (Gd) enhancing lesions on T1weighted scans is considered as evidence for acute inflammation and disruption of the BBB. Gd, a lanthanide chelate, is an extracellular contrast agent that requires relatively high local concentration to achieve sufficient contrast on MRI. Gadofluorine M (Gf), a new Gd-based agent, has been shown in in-vivo experimental studies to have a much higher sensitivity than Gd-DTPA in detecting disruption of the BBB on T1-weighted MRI (Bendszus et al., 2008).

The development and application of novel MR contrast agents allowing cellular and targeted molecular imaging hold promise in exploring inflammation and its regulation by 
cell adhesion molecules in MS. Contrast media composed of iron particles [superparamagnetic particles of iron oxide (SPIO) and ultrasmall particles of iron oxide (USPIO)] are more sensitive compared to Gd-containing agents at similar tissue concentrations (Liu \& Frank, 2009). The size of SPIO particles is $50-150 \mathrm{~nm}$ whereas that of USPIO particles is approximately $10-50 \mathrm{~nm}$. These particles are partly phagocytosed by circulating macrophages upon injection. When circulating macrophages are attracted to inflammatory lesions, they can be detected in vivo by MRI, since in tissue iron particles shorten both the $\mathrm{T} 1$ and T2 relaxation time (Vellinga et al., 2008). Several recent studies support the aspect that SPIO/USPIO enhanced MRI allows cellular neuroimaging (Baeten et al., 2008; Chin et al., 2009). Preliminary studies in RRMS patients have shown that some lesions may enhance only with Gd, others only with USPIO, and others with both. Moreover, the same lesions can change their pattern of enhancement over time (Vellinga et al., 2008). Furthermore, USPIO-enhanced MRI may not only disclose a greater number of 'active' MS lesions but may also detect subtle and diffuse inflammatory activity in MS patients not visible on conventional T2-weighted MR sequences and unrelated to Gd-DTPA enhancement (Vellinga et al., 2009).

Additionally, novel cellular MR contrast agents such as polyfluorinated nanoemulsions or activatable paramagnetic sensors and emerging molecular imaging approaches might give new insights into the MS inflammatory process. Myeloperoxidase (MPO) is one of the most abundant enzymes secreted by inflammatory cells and, thus, may serve as a marker of macrophage inflammation. It has been recently shown in an animal model of EAE that myeloperoxidase activity in inflamed tissues can be detected and labelled in vivo by a myeloperoxidase sensitive "smart" molecular imaging probe (JW Chen et al., 2008).

Transferring cellular and targeted molecular imaging approaches from in-vitro to in-vivo MRI and subsequently in clinical use holds promise for exploring MS neuroinflammation in the future.

\section{Optical techniques}

\subsection{Optical coherence tomography (OCT)}

Optical coherence tomography (OCT) is a new, sensitive, non-invasive, transpupilary method that allows direct imaging and quantification of the retinal nerve fibre layer (RNFL), which is principally composed of unmyelinated axons. By using an optical interferometer in conjunction with a low-coherence light source, OCT detects light reflections within a tissue and provides in vivo cross-sectional images at near microscopic resolution (Hrynchak \& Simpson, 2000; Huang et al., 1991). Recent advances in OCT allow differentiation of major retinal layers and analysis of tissue thickness and volume with a resolution of about $3 \mu \mathrm{m}$ (Ko et al., 2004).

Because the retina is the only place where a tissue layer made up of axons can be imaged directly, and the retina and optic nerve are often affected by MS, OCT can be used to assess the impact of MS on the retina by measuring the RNFL thickness and macular volume. The reductions of RNFL thickness and macular volume are associated with axonal loss and secondary retinal ganglion cell loss, respectively. Therefore, OCT shows promise in the detection, assessment and monitoring of neurodegeneration in MS (Barkhof et al., 2009; Petzold et al., 2010).

RNFL thinning has been detected with OCT about 3 months after acute optic neuritis. Moreover, continuing axonal loss in the affected eye for at least 12 months after optic 
neuritis has been found, more pronounced the first 6 months after injury (Costello et al., 2008). In addition, OCT has been shown to be predictive of a clinical outcome (poor visual recovery) (Costello et al., 2006). A recent meta-analysis of time domain OCT showed RNFL thinning in MS patients, both with and without a history of optic neuritis, more pronounced after optic neuritis (Petzold et al., 2010). The estimated RNFL thinning in patients with MS has been found to be greater than the extent expected in normal ageing and has been attributed to retrograde trans-synaptic degeneration and progressive loss of retinal ganglion cells, in addition to the more pronounced thinning observed in case of optic neuritis (Petzold et al., 2010). Furthermore, thinning of the RNFL in MS without optic neuritis was found to correlate with visual and neurological functioning, as well as with paraclinical data (Trip et al., 2005, 2006; Villoslada et al., 2008).

Macular volume loss has also been reported in patients with MS compared with controls, correlating with loss of RNFL (Burkholder et al., 2009; Trip et al., 2006). Recently, a subgroup of MS patients with primary retinal pathology characterized by predominant macular thinning has been described with the use of OCT, in whom there appears to be disproportionate thinning of the inner and outer nuclear retinal layers independent of optic nerve pathology. Moreover, these patients were shown to have accelerated disability progression, implying that this primary process may be associated with a more aggressive form of MS (Saidha et al., 2011).

OCT could be used for analysis of neurodegeneration in MS as well as for monitoring of treatment effects in trials of neuroprotective strategies in MS. Moreover, the integration of OCT into MS research could allow insights into the structure-function relations, thus improving our understanding of the pathophysiology of the disease.

\section{Conclusion}

Advances in neuroimaging have improved our ability to diagnose and monitor MS and have provided insight into the pathophysiology of the disease. Conventional MRI of the central nervous system plays a prominent role in establishing the diagnosis of MS and in differentiating MS-mimics and demyelinating disease subtypes. Moreover, it allows an earlier and accurate diagnosis of the disease, as it can support or even replace some clinical criteria. Early diagnosis is essential to allow earlier therapeutic intervention that appears to be beneficial on delaying the accumulation of irreversible neurologic damage and consequent disability.

In addition cMRI is a useful tool for monitoring disease progression as it is a sensitive imaging biomarker that detects pathological changes prior to the onset of clinical symptoms. Conventional MR scans are effective in detecting clinically silent new white matter inflammatory lesions. In particular, Gd-enhancing lesions are predictive of future clinical relapses. Therefore, cMRI is routinely used for detection of subclinical disease activity and for decisions regarding treatment in individual patients. Moreover, most clinical trials involving new treatments use MRI parameters as outcome measures to show therapeutic effectiveness. Besides Gd-enhancing and T2 lesions, CNS atrophy measurements are being increasingly used as primary MRI end point in clinical trials as they have been shown to be powerful predictors of clinical impairment, disease progression, and the accumulation of long-term physical and neuropsychological disability.

MRI serves also as a research tool in the study of MS. However, cMRI metrics have a limited ability to accurately determine the full extent of inflammatory and neurodegenerative 
pathological processes in MS. The discrepancy between clinical and MRI evolution in MS patients, often referred to as the "clinical-MRI paradox", has led to a growing interest in advanced techniques that can detect the presence of cortical lesions, subtle changes in the normal appearing white and gray matter, as well as adaptive functional changes that limit the clinical consequences of disease-related injury. The development and application of novel MR methods of acquisition and postprocessing aim to provide a more accurate characterization of tissue injury including demyelination, remyelination and axonal damage. These advanced approaches give also insights into the functional and metabolic consequences of MS. Additionally, the combined analysis of different magnetic resonance techniques, sensitive toward different aspects of MS, is likely to improve our understanding of the mechanisms responsible for the accumulation of irreversible neurological deficits in the disease. Emerging applications of these tools may also be useful in measuring the effect of therapies. Beyond MRI, novel imaging approaches such as OCT show promise in detecting and monitoring neurodegeneration in MS. Nevertheless, the new techniques and analysis procedures need to be refined and validated before they can be properly integrated into clinical research and practice. Until that time cMRI metrics will continue to play an important role in clinical practice and in clinical trials. Overuse of MRI in clinical practice, however, should be avoided. It is important to keep in mind that clinical judgment remains essential in the management of the disease and that careful interpretation of the MRI data is needed to avoid misdiagnosis.

\section{References}

Agosta, F. \& Filippi, M. (2007). MRI of spinal cord in multiple sclerosis. Journal of Neuroimaging, Vol.17, Suppl.1, (April 2007), pp. 46S-49S.

Anderson, VM.; Fox, NC. \& Miller DH. (2006). Magnetic resonance imaging measures of brain atrophy in multiple sclerosis. Journal of Magnetic Resonance Imaging, Vol.23, No.5, (May 2006), pp. 605-618.

Andreadou, E.; Papadimas, G. \& Sfagos, C. (2008). A novel heterozygous mutation in the NOTCH 3 gene causing CADASIL. Swiss Medical Weekly, (2008); Vol.138, No.41-42, (October 2008), pp. 614-617

Andreadou, E.; Papadimas, GK.; Sifakis, N. \& Sfagos, C. (2010). Corpus callosum infarct associated with combined variants in circle of Willis. Neurology India, Vol.58, No.5, (September-October 2010), pp. 785-786.

Audoin, B.; Ibarrola, D.; Ranjeva, J. P.; Confort-Gouny, S.; Malikova, I.; Ali-Cherif, A.; Pelletier, J. \& Cozzone, P. (2003). Compensatory cortical activation observed by fMRI during a cognitive task at the earliest stage of MS. Human Brain Mapping, Vol.20, No.2, (October 2003), pp. 51-58.

Baeten, K.; Hendriks, JJ.; Hellings, N.; Theunissen, E.; Vanderlocht, J.; Ryck, LD.; Gelan, J.; Stinissen, P. \& Adriaensens, P. (2008). Visualisation of the kinetics of macrophage infiltration during experimental autoimmune encephalomyelitis by magnetic resonance imaging. Journal of Neuroimmunology, Vol.195, No.1-2, (March 2008), pp. 1-6.

Bagnato, F.; JeVries, N.; Richert, ND. ; Stone, RD.; Ohayon, JM.; McFarland, HF. \& Frank, JA. (2003). Evolution of T1 black holes in patients with multiple sclerosis imaged monthly for 4 years. Brain, Vol.126, No.8, (August 2003), pp. 1782-1789. 
Bakshi, R.; Ariyaratana, S.; Benedict, RHB. \& Jacobs, L. (2001). Fluid-attenuated inversion recovery magnetic resonance imaging detects cortical and juxtacortical multiple sclerosis lesions. Archives of Neurology, Vol.58, No.5, (May 2001), pp. 742-748.

Bakshi, R.; Hutton, GJ.; Miller, JR. \& Radue, EW. (2004). The use of magnetic resonance imaging in the diagnosis and long-term management of multiple sclerosis. Neurology, Vol.63, Suppl. 5, (December 2004), pp. S3- S11.

Bakshi, R.; Thompson, AJ.; Rocca, MA.; Pelletier, D.; Dousset, V.; Barkhof, F.; Inglese, M.; Guttmann, CRG.; Horsfield, MA. \& Filippi, M. (2008). MRI in multiple sclerosis: current status and future prospects. Lancet Neurology, Vol.7, No.7, (July 2008), pp. 615-625

Barkhof, F.; Calabresi, PA.; Miller, DH. \& Reingold, SC. (2009). Imaging outcomes for neuroprotection and repair in multiple sclerosis trials. Nature Reviews, Neurology, Vol.5, No.5, (May 2009), pp. 256-266.

Barkhof, F.; Filippi, M.; Miller, DH.; Scheltens, P.; Campi, A.; Polman, CH.; Comi, G.; Adèr, HJ.; Losseff, N. \& Valk, J. (1997). Comparison of MRI criteria at first presentation to predict conversion to clinically definite multiple sclerosis. Brain, Vol.120, No. 11, (November 1997), pp. 2059-2069.

Barkhof, F. \& Scheltens, P. (2002). Imaging of white matter lesions. Cerebrovascular Diseases, Vol.13, Suppl.2, pp. 21-30.

Bates, DMA. (2011). Treatment effects of immunomodulatory therapies at different stages of multiple sclerosis in short-term trials. Neurology, Vol. 76, No.1 (Suppl 1), (January 2011), pp. S14-S25

Beck, RW.; Chandler, DL.; Cole, SR.; Simon, JH.; Jacobs, LD.; Kinkel, RP.; Selhorst, JB.; Rose, JW.; Cooper, JA.; Rice, G.; Murray, TJ. \& Sandrock, AW. (2002) Interferon beta-1a for early multiple sclerosis: CHAMPS trial subgroup analyses. Annals of Neurology, Vol.51, No.4, (April 2002), pp. 481-490.

Bendszus, M.; Ladewig, G.; Jestaedt, L.; Misselwitz, B.; Solymosi, L.; Toyka, K. \& Stoll, G. (2008). Gadofluorine $M$ enhancement allows more sensitive detection of inflammatory CNS lesions than T2-w imaging: a quantitative MRI study. Brain, Vol.131, No.9, (September 2008), pp. 2341-2352.

Bermel, RA. \& Bakshi, R. (2006). The measurement and clinical relevance of brain atrophy in multiple sclerosis. Lancet Neurology, Vol.5, No.2, (February 2006), pp. 158-170.

Brex, PA.; Ciccarelli, O. ; O’Riordan, JI.; Sailer, M.; Thompson, AJ \& Miller, DH. (2002). A longitudinal study of abnormalities on MRI and disability from multiple sclerosis. The New England Journal of Medicine, Vol.346, No.3, (January 2002), pp. 158-164.

Brex, PA.; Leary, SM. ; O’Riordan, JI.; Miszkiel, KA.; Plant, GT.; Thompson, AJ. \& Miller, DH. (2001). Measurement of spinal cord area in clinically isolated syndromes suggestive of multiple sclerosis. Journal of Neurology, Neurosurgery and Psychiatry, Vol. 70, No.4, (April 2001), pp. 544-547.

Brex, PA.; Parker, GJM.; Leary, SM.; Molyneux, PD.; Barker, GJ.; Davie, CA.; Thompson, AJ. \& Miller, DH. (2000). Lesion heterogeneity in multiple sclerosis: a study of the relations between appearances on $\mathrm{T} 1$ weighted images, $\mathrm{T} 1$ relaxation times, and metabolite concentrations. Journal of Neurology, Neurosurgery and Psychiatry, Vol.68, No.5, (May 2000), pp. 627-632.

Bot, JC.; Barkhof, F.; Lycklama à Nijeholt, G.; van Schaardenburg, D.; Voskuyl, AE.; Ader, HJ.; Pijnenburg, JA.; Polman, CH.; Uitdehaag, BM.; Vermeulen, EG.; Castelijns, JA. (2002). Differentiation of multiple sclerosis from other inflammatory disorders and 
cerebrovascular disease: value of spinal MR imaging. Radiology, Vol.223, No.1, (April 2002), pp. 46-56.

Bruck, W.; Bitsch, A.; Kolenda, H.; Brück, Y.; Stiefel, M. \& Lassmann, H. (1997). Inflammatory central nervous system demyelination: correlation of magnetic resonance imaging findings with lesion pathology. Annals of Neurology, Vol.42, No.5, (November 1997), pp. 783-793.

Burkholder, BM.; Osborne, B.; Loguidice, MJ.; Bisker, E.; Frohman, TC.; Conger, A.; Ratchford, JN.; Warner, C.; Markowitz, CE.; Jacobs, DA.; Galetta, SL.; Cutter, GR.; Maguire, MG.; Calabresi, PA.; Balcer, LJ. \& Frohman, EM. Macular volume determined by optical coherence tomography as a measure of neuronal loss in multiple sclerosis. Archives of Neurology, Vol.66, No.11, (November 2009), pp. 1366-1372.

Cader, S.; Cifelli, A.; Abu-Omar, Y.; Palace, J. \& Matthews, P.M. (2006). Reduced brain functional reserve and altered functional connectivity in patients with multiple sclerosis. Brain, Vol.129, No.2, (February 2006), pp. 527-537.

Calabrese M, Agosta F, Rinaldi F, Mattisi I, Grossi P, Favaretto A, Atzori M, Bernardi V, Barachino L, Rinaldi L, Perini P, Gallo P, Filippi M. (2009). Cortical lesions and atrophy associated with cognitive impairment in relapsing-remitting multiple sclerosis. Archives of Neurology, Vol.66, No.9 (September2006), pp. 1144-1150.

Calabrese, M.; De Stefano, N.; Atzori, M.; Bernardi, V.; Mattisi, I.; Barachino, L.; Morra, A.; Rinaldi, L.; Romualdi, C.; Perini, P.; Battistin, L. \& Gallo, P. (2007). Detection of cortical inflammatory lesions by double inversion recovery magnetic resonance imaging in patients with multiple sclerosis. Archives of Neurology, Vol.64, No.10, (October 2007), pp. 1416-1422.

Calabrese, M.; Filippi, M.; Rovaris, M.; Bernardi, V.; Atzori, M.; Mattisi, I.; Favaretto, A.; Grossi, P.; Barachino, L.; Rinaldi, L; Romualdi, C.; Perini, P. \& Gallo P. (2009a). Evidence for relative cortical sparing in benign multiple sclerosis: a longitudinal magnetic resonance imaging study. Multiple Sclerosis, 2009; Vol.15, No.1, (January 2009), pp. 36-41.

Calabrese, M.; Rocca, MA.; Atzori, M.; Mattisi, I.; Bernardi, V.; Favaretto, A.; Barachino, L.; Romualdi, C.; Rinaldi, L.; Perini, P.; Gallo, P. \& Filippi M. (2009b). Cortical lesions in primary progressive multiple sclerosis: a 2-year longitudinal MR study. Neurology Vol.72, No.15, (April 2009), pp. 1330-1336.

Calabrese, M.; Rocca, M.; Atzori, M.; Mattisi, I.; Favaretto, A.; Perini, P.; Gallo, P. \& Filippi, M. (2010). A three-year MRI study of cortical lesions in relapse-onset multiple sclerosis. Annals of Neurology,; Vol.67, No.3, (March 2010), pp. 376-383.

Campi, A.; Benndorf, G.; Filippi, M.; Reganati, P.; Martinelli, V. \& Terreni, MR. (2001). Primary angiitis of the central nervous system: serial MRI of brain and spinal cord. Neuroradiology, Vol. 43, No.8, (August 2001), pp. 599-607.

Caramanos, Z.; Narayanan, S. \& Arnold, DL. (2005). 1H-MRS quantification of tNA and tCr in patients with multiple sclerosis: a meta-analytic review. Brain, Vol.128, No.11, (November 2005), pp. 2483-2506.

Carone, DA.; Benedict, RH.; Dwyer, MG.; Cookfair, DL.; Srinivasaraghavan, B.; Tjoa, CW. \& Zivadinov, R. (2006b). Semi-automatic brain region extraction (SABRE) reveals superior cortical and deep gray matter atrophy in MS. Neuroimage, Vol.29, No.2, (January 2006), pp. 505-514.

Ceccarelli, A.; Rocca, MA.; Falini, A.; Tortorella P, Pagani E, Rodegher M, Comi G, Scotti G, Filippi M. (2007). Normal-appearing white and grey matter damage in MS: a 
volumetric and diffusion tensor MRI study at 3.0 Tesla. Journal of Neurology, Vol. 254, No.4, (April 2007), pp. 513-518

Chard, DT.; Griffin, CM.; McLean, MA.; Kapeller, P.; Kapoor, R.; Thompson, AJ. \& Miller, DH. (2002). Brain metabolite changes in cortical grey and normal-appearing white matter in clinically early relapsing-remitting multiple sclerosis. Brain, Vol. 125, No.10, (October 2002), pp. 2342-2352.

Charil, A.; Yousry, TA.; Rovaris, M.; Barkhof, F.; De Stefano, N.; Fazekas, F.; Miller, DH.; Montalban, X.; Simon, JH.; Polman, C. \& Filippi, M. (2006). MRI and the diagnosis of multiple sclerosis: expanding the concept of "no better explanation". Lancet Neurology, Vol.5, No.10, (October 2006), pp. 841-852.

Chen, JT.; Kuhlmann, T.; Jansen, GH.; Collins, DL.; Atkins, HL.; Freedman, MS.; O'Connor, PW.; Arnold, DL. \& Canadian MS/BMT Study Group. (2007). Voxel-based analysis of the evolution of magnetization transfer ratio to quantify remyelination and demyelination with histopathological validation in a multiple sclerosis lesion. Neuroimage,Vol.36, No.4, (July 2007), pp. 1152-1158.

Chen, JT., Collins, DL., Atkins, HL.; Freedman, MS.; Arnold, DL. \& Canadian MS/BMT Study Group. (2008). Magnetization transfer ratio evolution with demyelination and remyelination in multiple sclerosis lesions. Annals of Neurology, Vol. 63, No.2, (February 2008), pp. 254-262.

Chen, JW.; Breckwoldt, MO.; Aikawa, E.; Chiang, G. \& Weissleder, R. (2008). Myeloperoxidase-targeted imaging of active inflammatory lesions in murine experimental autoimmune encephalomyelitis. Brain, Vol.131, No.4, (April 2008), pp. 1123-1133.

Chin, CL.; Pai, M.; Bousquet, PF.; Schwartz, AJ.; O'Connor, EM.; Nelson, CM.; Hradil, VP.; Cox, BF.; McRae, BL. \& Fox, GB. (2009). Distinct spatiotemporal pattern of CNS lesions revealed by USPIO-enhanced MRI in MOG-induced EAE rats implicates the involvement of spinoolivocerebellar pathways. Journal of Neuroimmunology, Vol.211, No.1-2, (June 2009), pp. 49-55.

Ciccarelli, O.; Toosy, AT.; Hickman, SJ.; Parker, GJ.; Wheeler-Kingshott, CA.; Miller, DH. \& Thompson, AJ. (2005). Optic radiation changes after optic neuritis detected by tractography-based group mapping. Human Brain Mapping, Vol.25, No.3, (July 2005), 308-316.

Cordes, D.; Haughton, VM.; Arfanakis, K.; Wendt, GJ.; Turski, PA.; Moritz, CH.; Quigley, MA.; Meyerand, ME. (2000). Mapping functionally related regions of brain with functional connectivity MR imaging. American Journal of Neuroradiology, Vol.21, No. 9, (October 2000), pp. 1636-1644.

Costello, F.; Coupland, S.; Hodge, W.; Lorello, GR.; Koroluk, J.; Pan, YI.; Freedman, MS.; Zackon, DH. \& Kardon, RH. (2006). Quantifying axonal loss after optic neuritis with optical coherence tomography. Annals of Neurology, 2006; Vol.59, No.6, (June 2006), pp. 963-69.

Costello, F.; Hodge, W.; Pan, YI.; Eggenberger, E.; Coupland, S. \& Kardon, RH. (2008). Tracking retinal nerve fiber layer loss after optic neuritis: a prospective study using optical coherence tomography. Multiple Sclerosis, Vol.14, No.7, (August 2008), pp. 893-905.

Cotton, F.; Weiner, HL.; Jolesz, FA. \& Guttmann, CR. (2003). MRI contrast uptake in new lesions in relapsing-remitting MS followed at weekly intervals. Neurology, Vol.60, No.4, (February 2003), pp. 640-646. 
Davie, CA.; Barker, GJ.; Thompson, AJ.; Tofts, PS.; McDonald, WI. \& Miller, DH. (1997). 1H magnetic resonance spectroscopy of chronic cerebral white matter lesions and normal appearing white matter in multiple sclerosis. Journal of Neurology, Neurosurgery and Psychiatry, Vol. 63, No.6, (December 1997), pp. 736-742.

Davie, CA.; Hawkins, CP.; Barker, GJ.; Brennan, A.; Tofts, PS.; Miller, DH. \& McDonald WI. (1994). Serial proton magnetic resonance spectroscopy in acute multiple sclerosis lesions. Brain, Vol.117, No.1 (February 1994), pp. 49-58.

Dehmeshki, J.; Chard, DT.; Leary, SM.; Watt, HC.; Silver, NC.; Tofts, PS.; Thompson, AJ. \& Miller, DH. (2003). The normal appearing gray matter in primary progressive multiple sclerosis: a magnetisation transfer imaging study. Journal of Neurology, Vol.250, No1. (January 2003), pp. 67-74.

de Seze, J.; Stojkovic, T.; Ferriby, D.; Gauvrit, JY.; Montagne, C.; Mounier-Vehier, F.; Verier, A.; Pruvo, JP.; Hache, JC. \& Vermersch, P. (2002). Devic's neuromyelitis optica: clinical, laboratory, MRI and outcome profile. Journal of the Neurological Sciences, Vol.197, No.1-2, (May 2002), pp. 57-61.

De Stefano, N.; Filippi, M.; Miller, D.; Pouwels, PJ.; Rovira, A.; Gass, A.; Enzinger, C.; Matthews, PM. \& Arnold DL. (2007). Guidelines for using proton MR spectroscopy in multicenter clinical MS studies. Neurology, Vol.69, No.20, (November 2007), pp. 1942-1952.

De Stefano, N.; Matthews, PM.; Antel, JP.; Preul, M.; Francis, G. \& Arnold, DL. (1995). Chemical pathology of acute demyelinating lesions and its correlation with disability. Annals of Neurology, Vol.38, No.6, (December 1995), pp. 901-909.

Dichgans, M.; Holtmannspotter, M.; Herzog, J.; Peters, N.; Bergmann, M. \& Yousry, TA. (2002). Cerebral microbleeds in CADASIL: a gradient-echo magnetic resonance imaging and autopsy study. Stroke, Vol.33, No.1, (January 2002), pp. 67-71.

Di Filippo, M.; Anderson, VM.; Altmann, DR.; Swanton, JK.; Plant, GT.; Thompson, AJ. \& Miller, DH. (2010). Brain atrophy and lesion load measures over 1 year relate to clinical status after 6 years in patients with clinically isolated syndromes. Journal of Neurology, Neurosurgery and Psychiatry, Vol. 81, No.2, (February 2010), pp. 204-208.

Enzinger, C.; Smith, S.; Fazekas, F.; Drevin, G.; Ropele, S.; Nichols, T.; Behrens, T.; Schmidt, R. \& Matthews, PM. (2006). Lesion probability maps of white matter hyperintensities in elderly individuals: results of the Austrian stroke prevention study. Journal of Neurology, Vol.253, No.8, (August 2006), pp. 1064-1070

Fazekas, F.; Offenbacher, H.; Fuchs, S.; Schmidt, R.; Niederkorn, K.; Horne, S. \& Lechner H. (1988). Criteria for an increased specificity of MRI interpretation in elderly subjects with suspected multiple sclerosis. Neurology, Vol.38, No.12, (December 1988), pp. 1822-1825.

Ferguson, B.; Matyszak, M.K.; Esiri, M.M. \& Perry,VH. (1997). Axonal damage inacute multiple sclerosis lesions. Brain, Vol.120, No.3, (March 1997), pp. 393-399.

Filippi, M. \& Agosta, F. (2007). Magnetization transfer MRI in multiple sclerosis. Journal of Neuroimaging, Vol.17 (Suppl. 1), pp. 22S-26S.

Filippi, M. \& Agosta, F. (2009). Magnetic resonance techniques to quantify tissue damage, tissue repair, and functional cortical reorganization in multiple sclerosis. In: Progress in Brain Research, J. Verhaagen et al. (Eds.), Vol.175, pp. 465-482, ISSN 0079-6123

Filippi, M. \& Agosta, F. (2010). Imaging Biomarkers in Multiple Sclerosis. Journal of Magnetic Resonance Imaging, Vol.31, No.4, (April 2010), pp. 770-788. 
Filippi, M. \& Rocca, MA. (2007). Magnetization transfer magnetic resonance imaging of the brain, spinal cord, and optic nerve. Neurotherapeutics, Vol.4, No.3, (July 2007), pp. 401-13.

Filippi, M.; Rocca, MA.; Arnold, DL.; Bakshi, R.; Barkhof, F.; De Stefano, N.; Fazekas, F.; Frohman, E. \& Wolinsky, JS. (2006). EFNS guidelines on the use of neuroimaging in the management of multiple sclerosis. European Journal of Neurology, Vol.13, No. 4, (April 2006), pp. 313-325.

Filippi, M.; Rocca, MA.; Colombo, B.; Falini, A.; Codella, M.; Scotti, G. \& Comi, G. (2002). Functional magnetic resonance imaging correlates of fatigue in multiple sclerosis. Neuroimage, Vol.15, No.3, (March 2002), pp. 559-567.

Filippi, M.; Rocca, MA. \& Comi, G. (1998a). Magnetization transfer ratios of multiple sclerosis lesions with variable durations of enhancement. Journal of the Neurological Sciences, Vol.159, No.2, (August 1998), pp. 162-165.

Filippi, M., Rocca, M. A., Martino, G., Horsfield, M. A., \& Comi, G. (1998b). Magnetization transfer changes in the normal appearing white matter precede the appearance of enhancing lesions in patients with multiple sclerosis. Annals of Neurology, Vol.43, No.6, (June 1998), pp. 809-814.

Filippi, M.; Rossi, P.; Campi, A.; Colombo, B.; Pereira, C. \& Comi G. (1997). Serial contrastenhanced MR in patients with multiple sclerosis and varying levels of disability. American Journal of Neuroradiology, Vol.18, No.8, (September 1997), pp. 1549-1556.

Fisher, E.; Lee, JC.; Nakamura, K. \& Rudick, RA. (2008). Gray matter atrophy in multiple sclerosis: a longitudinal study. Annals of Neurology, Vol.64, No.3, (September 2008), pp. 255-265.

Freedman, MS. (2011). Long-term follow-up of clinical trials of multiple sclerosis therapies. Neurology, Vol.76, No.1(Suppl. 1), (January 2011), pp. S26-S34.

Ge, Y., Grossman, RI..; Udupa, JK.; Babb, JS.; Kolson, DL. \& McGowan, JC. (2001). Magnetization transfer ratio histogram analysis of gray matter in relapsingremitting multiple sclerosis. American Journal of Neuroradiology, Vol.22, No.3, (March 2001), pp. 470-475.

Ge, Y..; Grossman, RI.; Udupa, JK..; Wei, L.; Mannon, LJ.; Polansky, M. \& Kolson, DL. (2000). Brain atrophy in relapsing-remitting multiple sclerosis and secondary progressive multiple sclerosis: Longitudinal quantitative analysis. Radiology, Vol.214, No.3, (March 2000), pp. 665-670.

Gean-Marton, AD.; Vezina, LG. ; Marton, KI. ; Stimac, GK.; Peyster, RG.; Taveras, JM. \& Davis, KR. (1991). Abnormal corpus callosum: a sensitive and specific indicator of multiple sclerosis. Radiology, Vol.180, No.1, (July 1991), pp. 215-221.

Geurts, JJ.; Blezer, EL.; Vrenken, H.; van der Toorn, A.; Castelijns, JA.; Polman, CH.; Pouwels, PJ.; Bö, L. \& Barkhof, F. (2008). Does high-field MR imaging improve cortical lesion detection in multiple sclerosis? Journal of Neurology, Vol.255, No.2, (February 2008), pp. 183-191.

Geurts, JJ.; Pouwels, PJ.; Uitdehaag, BM.; Polman, CH.; Barkhof, F. \& Castelijns, JA. (2005). Intracortical lesions in multiple sclerosis: improved detection with 3D double inversion-recovery MR imaging. Radiology, Vol.236, No.1, (July 2005), pp. 254-260.

Gonen, O.; Catalaa, I.; Babb, JS.; Ge, Y.; Mannon, LJ.; Kolson, DL. \& Grossman, RI. (2000). Total brain N-acetylaspartate: a new measure of disease load in MS. Neurology, Vol.54, No.1, (January 2000), pp. 15-19.

Henry, RG.; Shieh, M.; Okuda, DT.; Evangelista, A.; Gorno-Tempini, ML. \& Pelletier D. (2008). Regional grey matter atrophy in clinically isolated syndromes at 
presentation. Journal of Neurology, Neurosurgery and Psychiatry, Vol.79, No.11, (November 2008), pp. 1236-1244.

Hillary, FG.; Chiaravalloti, N.D.; Ricker, J.H.; Steffener, J.; Bly, B.M.; Lange, G..; Liu, WC.; Kalnin, AJ. \& DeLuca, J. (2003). An investigation of working memory rehearsal in multiple sclerosis using fMRI. Journal of Clinical and Experimental Neuropsychology, Vol.25, No.7, (October 2003), pp. 965-978.

Horakova, D.; Dwyer, MG.; Havrdova, E.; Cox, JL.; Dolezal, O.; Bergsland, N.; Rimes, B.; Seidl, Z.; Vaneckova, M. \& Zivadinov, R. (2009). Gray matter atrophy and disability progression in patients with early relapsing-remitting multiple sclerosis: a 5-year longitudinal study. Journal of the Neurological Sciences, Vol.282, No.1-2, (July 2009), pp. 112-119.

Horsfield, MA.; Barker, GJ.; Barkhof, F.; Miller, DH.; Thompson, AJ. \& Filippi M. (2003). Guidelines for using quantitative magnetization transfer magnetic resonance imaging for monitoring treatment of multiple sclerosis. Journal of Magnetic Resonance Imaging, Vol.17, No.4, (April 2003), pp. 389-397.

Hrynchak, P. \& Simpson, T. (2000). Optical coherence tomography: An introduction to the technique and its use. Optometry and Vision Science, Vol.77, No.7, (July 2000), pp. 347-56.

Huang, D.; Swanson, EA.; Lin, CP.; Schuman, JS.; Stinson, WG.; Chang, W.; Hee, MR.; Flotte, T.; Gregory, K. \& Puliafito, CA. (1991). Optical coherence tomography. Science, Vol.254, No.5035, (November 1991), pp. 1178-1181.

Kangarlu, A.; Bourekas, EC.; Ray-Chaudhury, A. \& Rammohan, KW. (2007). Cerebral cortical lesions in multiple sclerosis detected by MR imaging at 8 Tesla. American Journal of Neuroradiology, Vol.28, No.2, (February 2007), pp. 262-266.

Kapeller, P.; McLean, MA.; Griffin, CM.; Chard, D.; Parker, GJ.; Barker, GJ.; Thompson, AJ. \& Miller, DH. (2001). Preliminary evidence for neuronal damage in cortical grey matter and normal appearing white matter in short duration relapsing-remitting multiple sclerosis: a quantitative MR spectroscopic imaging study. Journal of Neurology, Vol.248, No.2 (February 2001), pp. 131-138.

Kappos, L.; Moeri, D.; Radue, EW, Schoetzau A, Schweikert K, Barkhof F, Miller D, Guttmann CR, Weiner HL, Gasperini C, Filippi M. (1999). Predictive value of gadolinium-enhanced magnetic resonance imaging for relapse rate and changes in disability or impairment in multiple sclerosis: a meta-analysis. Lancet, Vol.353, No.9157, (March 1999), pp.964-969.

Ko, TH.; Fujimoto, JG.; Duker, JS.; Paunescu, LA.; Drexler, W.; Baumal, CR.; Puliafito, CA.; Reichel, E.; Rogers, AH. \& Schuman, JS. (2004). Comparison of ultrahigh- and standard-resolution optical coherence tomography for imaging macular hole pathology and repair. Ophthalmology, Vol.111, No.11, (November 2004), pp. 20332043.

Kutzelnigg, A.; Lucchinetti, CF.; Stadelmann, C.; Brück, W.; Rauschka, H.; Bergmann, M.; Schmidbauer, M.; Parisi, JE. \& Lassmann H. (2005). Cortical demyelination and diffuse white matter injury in multiple sclerosis. Brain, Vol.128, No.11, (November 2005), pp. 2705-2712.

Kwa, VI.; Stam, J.; Blok, LM. \& Verbeeten, BJr. (1997). T2-weighted hyperintense MRI lesions in the pons in patients with atherosclerosis. Amsterdam Vascular Medicine Group. Stroke Vol.28, No. pp. 1357-1360. 
Laule, C.; Vavasour, IM.; Whittall, KP.; Oger, J.; Paty, DW.; Li, DK. \& Arnold, DL. (2003). Evolution of focal and diffuse magnetisation transfer abnormalities in multiple sclerosis. Journal of Neurology, Vol.250, No.8, (August 2003), pp. 924-931.

Lee, M.; Reddy, H.; Johansen-Berg, H.; Pendlebury, S.; Jenkinson, M.; Smith, S.; Palace, J. \& Matthews, PM. (2000). The motor cortex shows adaptive functional changes to brain injury from multiple sclerosis. Annals of Neurology, Vol.47, No.5, (May 2000), pp. 606-613.

Lee, SH.; Yoon, PH.; Park, SJ. \& Kim, DI. (2001). MRI findings in neuro-Behçet's disease. Clinical Radiology, Vol.56, No.6, (June 2001), pp. 485-494.

Li, DK.; Held, U.; Petkau, J.; Daumer, M.; Barkhof, F.; Fazekas, F.; Frank, JA.; Kappos, L.; Miller, DH.; Simon, JH,.; Wolinsky, JS,; Filippi, M. \& Sylvia Lawry Centre for MS Research. (2006). MRI T2 lesion burden in multiple sclerosis: a plateauing relationship with clinical disability. Neurology, 66, No.9, (May 2006), pp. 1384-1389.

Li, Y.; Chiaravalloti, ND.; Hillary, FG.; Deluca, J.; Liu, WC.; Kalnin, AJ. \& Ricker JH. (2004). Differential cerebellar activation on functional magnetic resonance imaging during working memory performance in persons with multiple sclerosis. Archives of Physical Medicine and Rehabilitation, Vol.85, No.4, (April 2004), pp. 635-639.

Liu, W, \& Frank, JA. (2009). Detection and quantification of magnetically labelled cells by cellular MRI. European Journal of Radiology, Vol.70, No.2, (May 2009), pp. 258-264.

Logothetis, NK.; Pauls, J.; Augath, M.; Trinath, T. \& Oeltermann, A. (2001). Neurophysiological investigation of the basis of the fMRI signal. Nature, Vol. 412, No.6843, (July, 2001), pp. 150-157.

Lowe, MJ.; Beall, EB.; Sakaie, KE.; Koenig, KA.; Stone, L.; Marrie, RA. \& Phillips, MD. (2008). Resting state sensorimotor functional connectivity in multiple sclerosis inversely correlates with transcallosal motor pathway transverse diffusivity. Hum. Brain Mapp. Vol.29, No.7, (July 2008), pp. 818-827.

Lowe, MJ.; Horenstein, C.; Hirsch, JG.; Marrie, RA.; Stone, L.; Bhattacharyya, PK.; Gass, A. \& Phillips, MD. (2006). Functional pathway-defined MRI diffusion measures reveal increased transverse diffusivity of water in multiple sclerosis. NeuroImage, Vol.32, No.3, (September 2006), pp. 1127-1133.

Lucchinetti, C.; Brück, W.; Parisi, J.; Scheithauer, B.; Rodriguez, M. \& Lassmann, H. (2000). Heterogeneity of multiple sclerosis lesions: implications for the pathogenesis of demyelination. Annals of Neurology, Vol.47, No.6, (June 2000), pp. 707-717.

Lycklama, G.; Thompson, A.; Filippi, M.; Miller, D.; Polman, C.; Fazekas, F. \& Barkhof, F. (2003). Spinal-cord MRI in multiple sclerosis. Lancet Neurology, Vol.2, No.9, (September 2003), pp. 555-562.

Markovic-Plese, S. \& McFarland, HF. (2001). Immunopathogenesis of the multiple sclerosis lesion. Current Neurology and Neuroscience Reports, Vol.1, No.3, (May 2001), pp. 257262.

Martola, J.; Stawiarz, L.; Fredrikson, S.; Hillert, J.; Bergström, J.; Flodmark, O. \& Kristoffersen Wiberg M. (2007). Progression of non age-related callosal brain atrophy in multiple sclerosis: a 9-year longitudinal MRI study representing four decades of disease development. Journal of Neurology, Neurosurgery and Psychiatry, Vol.78, No.4, (April 2007), pp. 375-380.

Masdeu, JC.; Moreira, J.; Trasi, S.; Visintainer, P.; Cavaliere, R. \& Grundman, M. (1996). The open ring: a new imaging sign in demyelinating disease. Journal of Neuroimaging, Vol.6, No.2, (April 1996), pp. 104-107. 
McDonald, WI.; Compston, A.; Edan, G.; Goodkin, D.; Hartung, HP.; Lublin, FD.; McFarland, HF.; Paty, DW.; Polman, CH.; Reingold, SC.; Sandberg-Wollheim, M.; Sibley, W.; Thompson, A.; van den Noort, S.; Weinshenker, BY. \& Wolinsky, JS. (2001). Recommended diagnostic criteria for multiple sclerosis: guidelines from the International Panel on the diagnosis of multiple sclerosis. Annals of Neurology, Vol.50, No.1, (July 2001), pp. 121-127.

Miller, D.; Barkhof, F.; Montalban, X.; Thompson, A. \& Filippi, M. (2005). Clinically isolated syndromes suggestive of multiple sclerosis, part 2: non-conventional MRI, recovery processes, and management. Lancet Neurology, Vol.4, No.6, (June 2005), pp. 341-348.

Miller, DH.; Soon, D.; Fernando, KT.; MacManus, DG..;Barker, GJ.; Yousry, TA.; Fisher, E.; O'Connor, P.;, Phillips, JT,.; Polman, CH.; Kappos, L.; Hutchinson, M.; Havrdova, E.; Lublin, FD.; Giovannoni, G.; Wajgt, A.; Rudick, R.; Lynn, F.; Panzara, MA.; Sandrock, AW. \& AFFIRM Investigators. (2007). MRI outcomes in a placebo controlled trial of natalizumab in relapsing MS. Neurology, Vol.68, No.17, (April 2007), pp. 1390-1401.

Miller, DH.; Weinshenker, BG.; Filippi, M.; Banwell, BL.; Cohen, JA.; Freedman, MS.; Galetta, SL.; Hutchinson M, Johnson RT, Kappos, L.; Kira, J.; Lublin, FD.; McFarland, HF.; Montalban, X.; Panitch, H.; Richert, JR.; Reingold, SC. \& Polman, $\mathrm{CH}$. (2008). Differential diagnosis of suspected multiple sclerosis: a consensus approach. Multiple Sclerosis, Vol.14, No.9, (November 2008), pp.1157-1174.

Minneboo, A.; Uitdehaag, BM.; Ader, HJ.; Barkhof, F.; Polman, CH. \& Castelijns, JA. (2005). Patterns of enhancing lesion evolution in multiple sclerosis are uniform within patients. Neurology, Vol.65, No.1, (July 2005), pp. 56-61.

Molyneux, PD.; Barker, GJ.; Barkhof, F.; Beckmann, K.; Dahlke, F.; Filippi, M.; Ghazi, M.; Hahn, D,.; MacManus, D.; Polman, C.; Pozzilli, C.; Kappos, L,.;Thompson, AJ.; Wagner, K.; Yousry, T. \& Miller, DH; European Study Group on Interferon Beta-1b in Secondary Progressive MS. (2001). Clinical-MRI correlations in a European trial of interferon beta-1b in secondary progressive MS. Neurology, Vol.57, No.12, (December 2001), pp. 2191-2197.

Molyneux, PD.; Filippi, M.; Barkhof, F.; Gasperini, C.; Yousry, TA.; Truyen, L.; Lai, HM.; Rocca, MA.; Moseley, IF. \& Miller, DH. (1998). Correlations between monthly enhanced MRI lesion rate and changes in T2 lesion volume in multiple sclerosis. Annals of Neurology, Vol.43, No.3, (March 1998), pp. 332-339.

Mori, S.; Kaufmann, WE.; Davatzikos, C.; Stieltjes, B.; Amodei, L.; Fredericksen, K.; Pearlson, GD.; Melhem, ER.; Solaiyappan, M.; Raymond, GV.; Moser HW. \& van Zijl, PC. (2002). Imaging cortical association tracts in the human brain using diffusiontensor- based axonal tracking. Magnetic Resonance in Medicine, Vol.47, No.2, (February 2002), pp. 215-223.

Morgen, K.; Jeffries, NO.; Stone, R.; Martin, R.; Richert, ND.; Frank, JA. \& McFarland, HF. (2001). Ring-enhancement in multiple sclerosis: marker of disease severity. Multiple Sclerosis, Vol.7, No.3, (June 2001), pp. 167-171.

Narayana, PA. (2005). Magnetic resonance spectroscopy in the monitoring of multiple sclerosis. Journal of Neuroimaging, Vol.15, Suppl.4, pp. 46S-57S.

Narayana, PA.; Doyle, T.J. Lai, D., \& Wolinsky, J.S. (1998). Serial proton magnetic resonance spectroscopic imaging, contrast-enhanced magnetic resonance imaging, and quanti- tative lesion volumetry in multiple sclerosis. Annals of Neurology, Vol.43, No.1, (January 1998), pp. 56-71. 
Ogawa, S.; Lee, TE.; Kay, AR. \& Tank, DW. (1990). Brain magnetic resonance imaging with contrast dependent on blood oxygenation. Proceedings of the National Academy of Sciences of the United States of America, Vol.87, No.24, (December 1990), pp. 9868-9872.

Oh, J.; Henry, R. G.; Genain, C.; Nelson, SJ. \& Pelletier, D. (2004). Mechanisms of normal appearing corpus callosum injury related to pericallosal T1 lesions in multiple sclerosis using directional diffusion tensor and H MRS imaging. Journal of Neurology Neurosurgery and Psychiatry, Vol.75, No.9, (September 2004), pp. 1281-1286.

O'Sullivan, M.; Jarosz, JM.; Martin, RJ.; Deasy, N.; Powell, JF. \& Markus, HS. (2001). MRI hyperintensities of the temporal lobe and external capsule in patients with CADASIL. Neurology, Vol.56, No.5, (March 2001), pp. 628-634.

Pagani, E.; Rocca, MA.; Gallo, A.; Rovaris, M.; Martinelli, V.; Comi, G. \& Filippi, M. (2005). Regional brain atrophy evolves differently in patients with multiple sclerosis according to clinical phenotype. American Journal of Neuroradiology, Vol.26, No.2, (February 2005), pp. 341-346.

Pagani, E.; Bammer, R.; Horsfield, MA.; Rovaris, M.; Gass, A.; Ciccarelli, O. \& Filippi, M. (2007). Diffusion MR imaging in multiple sclerosis: technical aspects and challenges. American Journal of Neuroradiology, Vol.28, No.3, (March 2007), pp. 411-420.

Paty, DW.; Oger, JF.; Kastrukoff, LF.; Hashimoto, SA.; Hooge, JP.; Eisen, AA.; Eisen, KA.; Purves, SJ.; Low, MD. \& Brandejs, V. (1988). MRI in the diagnosis of MS: a prospective study with comparison of clinical evaluation, evoked potentials, oligoclonal banding, and CT. Neurology, Vol.38, No.2, (February 1988), pp. 180-185.

Penner, IK.; Rausch, M.; Kappos, L.; Opwis, K. \& Radu, EW. (2003). Analysis of impairment related functional architecture in MS patients during performance of different attention tasks. Journal of Neurology, Vol.250, No.4, (April 2003), pp. 461-472.

Petzold, A.; de Boer, JF.; Schippling, S.; Vermersch, P.; Kardon, R.; Green, A.; Calabresi, PA. \& Polman, C. (2010). Optical coherence tomography in multiple sclerosis: a systematic review and meta-analysis. Lancet Neurology, Vol.9, No.9, (September 2010), pp. 921-932.

Polman, CH.; Reingold, SC.; Edan, G.; Filippi, M.; Hartung, HP.; Kappos, L.; Lublin, FD.; Metz, LM.; McFarland, HF.; O'Connor, PW.; Sandberg-Wollheim, M.; Thompson, AJ.; Weinshenker, BG. \& Wolinsky, JS. (2005). Diagnostic criteria for multiple sclerosis: 2005 revisions to the "McDonald Criteria". Annals of Neurology, Vol.58, No.6, (December 2005), pp. 840-846

Polman, CH.; Reingold, SC.; Banwell, B.; Clanet, M.; Cohen, JA.; Filippi, M.; Fujihara, K.; Havrdova, E.; Hutchinson, M.; Kappos, L.; Lublin, FD.; Montalban, X.; O'Connor, P.; Sandberg-Wollheim, M.; Thompson, AJ.; Waubant, E.; Weinshenker, B. \& Wolinsky, JS. (2011). Diagnostic criteria for multiple sclerosis: 2010 revisions to the McDonald criteria. Annals of Neurology, Vol.69, No.2, (February 2011), pp. 292-302.

Poonawalla, AH.; Hasan, KM.; Gupta, RK.; Ahn, CW.; Nelson, F.; Wolinsky, JS. \& Narayana, PA. (2008). Diffusion-tensor MR imaging of cortical lesions in multiple sclerosis: initial findings. Radiology, Vol.246, No.3, (March 2008), pp. 880-886.

Poser, CM.; Paty, DW.; Scheinberg, L.; McDonald, WI.; Davis, FA.; Ebers, GC.; Johnson, KP.; Sibley, WA.; Silberberg, DH. \& Tourtellotte, WW. (1983). New diagnostic criteria for multiple sclerosis: guidelines for research protocols. Annals of Neurology, Vol.13, No.3, (March 1983), pp. 227-231.

Ranjeva, JP.; Audoin, B.; Au Duong, MV.; Ibarrola, D.; Confort-Gouny, S.; Malikova, I.; Soulier, E.; Viout, P.; Ali-Chérif, A.; Pelletier, J. \& Cozzone, P. (2005). Local tissue 
damage assessed with statistical mapping analysis of brain magnetization transfer ratio: relationship with functional status of patients in the earliest stage of multiple sclerosis. American Journal of Neuroradiology, Vol.26, No.1, (January 2005), pp. 119-127.

Reddy, H.; Narayanan, S,.;Arnoutelis, R.; Jenkinson, M.; Antel, J.; Matthews, PM. \& Arnold, DL. (2000). Evidence for adaptive functional changes in the cerebral cortex with axonal injury from multiple sclerosis. Brain, Vol.123, No.11, (November 2000), pp. 2314-2320.

Rocca, M.; Agosta, F.; Sormani, MP.; Fernando, K.; Tintorè, M.; Korteweg, T.; Tortorella, P.; Miller, DH.; Thompson, A.; Rovira, A,.;Montalban, X.; Polman, C.; Barkhof, F. \& Filippi, M. (2008). A three-year, multi-parametric MRI study in patients at presentation with CIS. Journal of Neurology, Vol. 255, No.5, (May 2008), pp. 683-691.

Rocca, MA.; Colombo, B.; Falini, A.; Ghezzi, A.; Martinelli, V.; Scotti, G.; Comi, G. \& Filippi, M (2005). Cortical adaptation in patients with MS: a cross-sectional functional MRI study of disease phenotypes. Lancet Neurology, Vol.4, No.10, (October 2005), pp. 618-626.

Rocca, MA.; Mezzapesa, DM.; Falini, A.; Ghezzi, A.; Martinelli, V.; Scotti, G.; Comi, G. \& Filippi, M. (2003). Evidence for axonal pathology and adaptive cortical reorganisation in patients at presentation with clinically isolated syndromes suggestive of MS. NeuroImage, Vol.18, No.4, (April 2003), pp. 847-855.

Roosendaal, SD.; Moraal, B.; Pouwels, PJ.; Vrenken, H.; Castelijns, JA.; Barkhof, F. \& Geurts, JJ. (2009). Accumulation of cortical lesions in MS: relation with cognitive impairment. Multiple Sclerosis, Vol.15, No.6, (June 2009), pp. 708-714.

Rovaris, M. (2008). The definition of non-responder to multiple sclerosis treatment: neuroimaging markers. Neurological Scienses, Vol.29, Suppl.2, (September 2008), pp. S222-S224.

Rovaris, M.; Agosta, F.; Sormani, MP.; Inglese, M.; Martinelli, V.; Comi, G. \& Filippi, M. (2003). Conventional and magnetization transfer MRI predictors of clinical multiple sclerosis evolution: a medium-term follow-up study. Brain, Vol.126, No.10, (October 2003), pp. 2323-2332.

Rovaris, M.; Bozzali, M.; Santuccio, G.; Ghezzi, A.; Caputo, D.; Montanari, E.; Bertolotto, A.; Bergamaschi, R.; Capra, R,.; Mancardi, G.; Martinelli, V.; Comi, G. \& Filippi, M. (2001). In vivo assessment of the brain and cervical cord pathology of patients with primary progressive multiple sclerosis. Brain, Vol.124, No.12, (December 2001), pp. 2540-2549.

Rovaris, M.; Gass, A.; Bammer, R.; Hickman, SJ.; Ciccarelli, O.; Miller, DH. \& Filippi, M. (2005). Diffusion MRI in multiple sclerosis. Neurology, Vol.65, No.10, (November 2005), pp. 1526-1532.

Rovaris, M.; Viti, B.; Ciboddo, G.; Capra, R. \& Filippi, M. (2000). Cervical cord magnetic resonance imaging findings in systemic immune-mediated diseases. Journal of the Neurological Scienses, Vol. 176, No.2, (June 2000), pp. 128-130.

Rovira, A.; Alonso, J.; Cucurella, G.; Nos, C.; Tintore, M.; Pedraza, S.; Rio, J. \& Montalban, X. (1999). Evolution of multiple sclerosis lesions on serial contrast-enhanced T1weighted and magnetization-transfer MR images. American Journal of Neuroradiology, Vol.20, No.10, (November-December 1999), pp. 1939-1945.

Rudick, RA. (2004). Impact of disease-modifying therapies on brain and spinal cord atrophy in multiple sclerosis. Journal of Neuroimaging, Vol.14, Suppl.3, (July 2004), pp. 54S-64S. 
Rudick, RA.; Lee, JC.; Simon J.; Ransohoff, RM. \& Fisher, E. (2004). Defining interferon beta response status in multiple sclerosis patients. Annals of Neurology, Vol.56, No.4, (October 2004), pp. 548-555.

Saidha, S.; Syc, SB.; Ibrahim, MA.; Eckstein, C.; Warner, CV.; Farrell, SK.; Oakley, JD.; Durbin, MK.; Meyer, SA.; Balcer, LJ.; Frohman, EM.; Rosenzweig, JM.; Newsome, SD.; Ratchford, JN.; Nguyen, QD. \& Calabresi, PA. (2011). Primary retinal pathology in multiple sclerosis as detected by optical coherence tomography. Brain, Vol. 134, No.2, (February 2011), pp. 518-533.

Sailer, M.; Losseff, NA.; Wang, L.; Gawne-Cain, ML.; Thompson, AJ. \& Miller, DH. (2001). T1 lesion load and cerebral atrophy as a marker for clinical progression in patients with multiple sclerosis: a prospective 18 months follow-up study. European Journal of Neurology, Vol.8, No.1, (January 2001), pp. 37-42.

Santos, AC.; Narayanan, S.,;De Stefano, N.; Tartaglia, MC.; Francis, SJ.; Arnaoutelis, R.; Caramanos, Z.; Antel, JP.; Pike, GB. \& Arnold, DL. (2002). Magnetization transfer can predict clinical evolution in patients with multiple sclerosis. Journal of Neurology, Vol.249, No.6 (June 2002), pp. 662-668.

Sastre-Garriga, J.; Ingle, G.T., Chard, D.T., Ramió-Torrenta', L., McLean, M.A., Miller, D.H. \& Thompson AJ. (2005). Metabolite changes in normal-appearing gray and white matter are linked with disability in early primary progressive multiple sclerosis. Archives of Neurology, Vol.62, No.4, (April 2005), pp. 569-573.

Schmierer, K.; Scaravilli, F.; Altmann, D.R.; Barker, G.J. \& Miller, D.H. (2004). Magnetization transfer ratio and myelin in postmortem multiple sclerosis brain. Annals of Neurology, Vol.56, No.3, (September 2004), pp. 407-415.

Schumacker, GA.; Beebe, G.; Kibler, RF.; Kurland, LT.; Kurtzke, JF.; Mcdowell, F.; Nagler, B.; SIBibley, WA.; Tourtellotte, WW. \& Willmon, TL. (1965). Problems of experimental trials of therapy in multiple sclerosis: report by the panel on the evaluation of experimental trials of therapy in multiple sclerosis. Annals of the New York Academy of Sciences, Vol. 122, (March 1965), pp. 552-568.

Sicotte, NL.; Voskuhl, RR.; Bouvier, S.; Klutch R, Cohen, MS. \& Mazziotta, JC. (2003). Comparison of multiple sclerosis lesions at 1.5 and 3.0 T. Investigative Radiology, Vol.38, No.7, (July 2003), pp. 423-427.

Silver, NC.; Lai, M.; Symms, MR.; Barker, GJ.; McDonald, WI. \& Miller, DH. (1998). Serial magnetization transfer imaging to characterize the early evolution of new MS lesions. Neurology, Vol.51, No.3, (September 1998), pp. 758-764.

Simon, JH.; Zhang, S.; Laidlaw, DH.; Miller, DE.; Brown, M.; Corboy, J. \& Bennett, J. (2006). Identification of fibers at risk for degeneration by diffusion tractography in patients at high risk for MS after a clinically isolated syndrome. Journal of Magnetic Resonance Imaging, Vol.24, No.5, (November 2006), pp. 983-988.

Singhal, S.; Rich, P. \& Markus, HS. (2005). The spatial distribution of MR imaging abnormalities in cerebral autosomal dominant arteriopathy with subcortical infarcts and leukoencephalopathy and their relationship to age and clinical features. AJNR Am J Neuroradiol (2005), Vol.26, No. pp. 2481-87.

Song, SK.; Yoshino, J.; Le, TQ.; Lin, S. J.; Sun, S. W.; Cross, AH. \& Armstrong, RC. (2005). Demyelination increases radial diffusivity in corpus callosum of mouse brain. NeuroImage, Vol.26, No.1, (May 2005), pp. 132-140.

Srinivasan, R.; Ratiney, H.; Hammond-Rosenbluth, KE.; Pelletier, D. \& Nelson, SJ. (2010). MR spectroscopic imaging of glutathione in the white and gray matter at $7 \mathrm{~T}$ with 
an application to multiple sclerosis. Magnetic Resonance Imaging, Vol.28, No.2, (February 2010), pp. 163-170.

Srinivasan, R.; Sailasuta, N.; Hurd, R.; Nelson, S. \& Pelletier, D. (2005). Evidence of elevated glutamate in multiple sclerosis using magnetic resonance spectroscopy at 3 T. Brain, Vol.128, No.5, (May 2005), pp. 1016-1025.

Srinivasan, R.; Vignerion, D.; Sailasuta, N.; Hurd, R. \& Nelson, S. (2004). A comparative study of myo-inositol quantification using LC model at $1.5 \mathrm{~T}$ and $3.0 \mathrm{~T}$ with $3 \mathrm{D} 1 \mathrm{H}$ proton spectroscopic imaging of the human brain. Magnetic Resonance Imaging, Vol.22, No.4, (May 2004), pp. 523-528.

Staffen, W.; Mair, A.; Zauner, H.; Unterrainer, J.; Niederhofer, H.; Kutzelnigg, A.; Ritter, S.; Golaszewski, S.; Iglseder, B. \& Ladurner, G. (2002). Cognitive function and fMRI in patients with multiple sclerosis: evidence for compensatory cortical activation during an attention task. Brain, Vol.125, No.6, (June 2002), pp. 1275-1282.

Stankiewicz, JM.; Neema, M.; Alsop, DC.; Healy, BC.; Arora, A.; Buckle, GJ.; Chitnis, T.; Guttmann, CR.; Hackney, D. \& Bakshi, R. (2009). Spinal cord lesions and clinical status in multiple sclerosis: a $1.5 \mathrm{~T}$ and $3 \mathrm{~T}$ MRI study. Journal of the Neurological Sciences, Vol.279, No.1-2, (April 2009), pp. 99-105.

Stankiewicz, J.; Panter, SS.; Neema, M.; Arora, A.; Batt, CE. \& Bakshi, R. Iron in chronic brain disorders: imaging and neurotherapeutic implications. Neurotherapeutics, Vol.4, No.3, (July 2007), pp. 371-386.

Stevenson, VL.; Ingle, GT.; Miller, DH. \& Thompson, AJ. (2004). Magnetic resonance imaging predictors of disability in primary progressive multiple sclerosis: A 5-year study. Multiple Sclerosis, Vol.10, No.4, (August 2004), pp. 398-401.

Summers, M.; Swanton, J.; Fernando, K.; Dalton C, Miller, DH, Cipolotti, L \& Ron, MA. (2008). Cognitive impairment in multiple sclerosis can be predicted by imaging early in the disease. Journal of Neurology, Neurosurgery and Psychiatry, Vol. 79, No.8, (August 2008), pp. 955-958.

Swanton, JK.; Fernando, KT.; Dalton, CM.; Miszkiel, KA.; Thompson, AJ.; Plant, GT. \& Miller, DH. (2006). Modification of MRI criteria for multiple sclerosis in patients with clinically isolated syndromes. Journal of Neurology, Neurosurgery and Psychiatry, Vol. 77, No.7, (July 2006), pp. 830-833.

Swanton, JK.; Rovira, A.; Tintore, M.; Altmann, DR.; Barkhof, F.; Filippi, M.; Huerga, E.; Miszkiel, KA.; Plant, GT.; Polman, C.; Rovaris, M.; Thompson, AJ.; Montalban, X. \& Miller, DH. (2007). MRI criteria for multiple sclerosis in patients presenting with clinically isolated syndromes: a multicentre retrospective study. Lancet Neurology, Vol.6, No.8, (August 2007), pp. 677-686.

Theodoridou, A. \& Settas, L. (2008). Demyelination in rheumatic diseases. Postgraduate Medical Journal, Vol.84, No.989, (March 2008), pp. 127-132.

Tintore, M.; Rovira, A.; Martinez, M.; Rio, J.; Díaz-Villoslada, P.; Brieva, L.; Borrás, C.; Grivé, E.; Capellades, J. \& Montalban, X. (2000). Isolated demyelinating syndromes: comparison of different MR imaging criteria to predict conversion to clinically definite multiple sclerosis. American Journal of Neuroradiology, Vol.21, No.4, (April 2000), pp. 702-706.

Tintore, M.; Rovira, A.; Rio, J.; Nos, C.; Grivé, E.; Téllez, N.; Pelayo, R.; Comabella, M.; Sastre-Garriga, J. \& Montalban, X. (2006). Baseline MRI predicts future attacks and disability in clinically isolated syndromes. Neurology, Vol. 67, No. 6, (September, 2006), pp. 968-972. 
Thompson, AJ.; Montalban, X.; Barkhof, F.; Brochet, B.; Filippi, M.; Miller, DH.; Polman, CH.; Stevenson, VL. \& McDonald, WI. (2000). Diagnostic criteria for primary progressive multiple sclerosis: a position paper. Annals of Neurology, Vol.47, No. 6, (June 2000), pp. 831-835.

Tovar-Moll, F.; Evangelou, IE.; Chiu, AW.; Richert, ND.; Ostuni, JL.; Ohayon, JM.; Auh, S.; Ehrmantraut, M.; Talagala SL.; McFarland, HF. \& Bagnato F. (2009). Thalamic involvement and its impact on clinical disability in patients with multiple sclerosis: A diffusion tensor imaging study at 3T. American Journal of Neuroradiology, Vol.30, No.7, (August 2009), pp. 1380-1386.

Trip, SA.; Schlottmann, PG.; Jones, SJ.; Altmann, DR.; Garway-Heath, DF.; Thompson, AJ.; Plant, GT. \& Miller, DH. (2005). Retinal nerve fiber layer axonal loss and visual dysfunction in optic neuritis. Annals of Neurology, Vol.58, No.3, (September 2005), pp. 383-391.

Trip, SA.; Schlottmann, PG.; Jones, SJ.; Li, WY.; Garway-Heath, DF.; Thompson, AJ.; Plant, GT. \& Miller, DH. (2006). Optic nerve atrophy and retinal nerve fibre layer thinning following optic neuritis: evidence that axonal loss is a substrate of MRI-detected atrophy. Neuroimage, Vol.31, No.1, (May 2006), pp. 286-293.

Truyen, L.; van Waesberghe, JH.; van Walderveen, MA.; van Oosten, BW.; Polman, CH.; Hommes, OR.; Adèr, HJ. \& Barkhof, F. (1996). Accumulation of hypointense lesions ("black holes") on T1 spin-echoMRI correlates with disease progression in multiple sclerosis. Neurology, Vol.47, No.6, (December 1996), pp. 1469-1476.

van Buchem, MA.; McGowan, JC.; Kolson, DL.; Polansky, M. \& Grossman, RI. (1996). Quantitative volumetric magnetization transfer analysis in multiple sclerosis: Estimation of macroscopic and microscopic disease burden. Magnetic Resonance in Medicine, Vol.36, No.4, (October 1996), pp. 632-636.

van den Heuvel, MP. \& Hulshoff Pol, HE. (2010). Exploring the brain network: A review on resting-state fMRI functional connectivity. European Neuropsychopharmacology, Vol.20, No.8, (August 2010), pp. 519-534

van Waesberghe, JH.; van Walderveen, MA.; Castelijns, JA.; Scheltens, P.; Lycklama à Nijeholt, GJ.; Polman, CH. \& Barkhof, F. (1998). Patterns of lesion development in multiple sclerosis: longitudinal observations with T1-weighted spin-echo and magnetization transfer MR. American Journal of Neuroradiology, Vol.19, No.4, (April 1998), pp. 675-683.

van Walderveen, MA.; Kamphorst, W.; Scheltens, P,.; van Waesberghe, JH.; Ravid, R.; Valk, J.; Polman, CH. \& Barkhof, F. (1998). Histopathologic correlate of hypointense lesions on T1-weighted spin-echo MRI in multiple sclerosis. Neurology, Vol.50, No.5, (May 1998), pp. 1282-1288.

Vellinga, MM.; Oude Engberink, RD.; Seewann, A.; Pouwels, PJ.; Wattjes, MP.; van der Pol, SM.; Pering, C.; Polman, CH.; de Vries, HE.; Geurts, JJ. \& Barkhof, F. (2008). Pluriformity of inflammation in multiple sclerosis shown by ultra-small iron oxide particle enhancement. Brain Vol.131, No.3, (March 2008), pp. 800-807.

Vellinga, MM.; Vrenken, H.; Hulst, HE.; Polman, CH.; Uitdehaag, BM.; Pouwels, PJ.; Barkhof, F. \& Geurts, JJ. (2009). Use of ultrasmall superparamagnetic particles of iron oxide (USPIO)-enhanced MRI to demonstrate diffuse inflammation in the normal-appearing white matter (NAWM) of multiple sclerosis (MS) patients: an exploratory study. Journal of Magnetic Resonance Imaging, Vol.29, No.4, (April 2009), pp.774- 779 . 
Villoslada, P.; Sepulcre, J.; Toledo, J. \& Bejarano, B. (2008). Retinal nerve fiberfibre layer is associated with brain atrophy in multiple sclerosis. Neurology, Vol.71, No.21, (November 2008), pp. 1747.

Wattjes, MP. \& Barkhof, F. (2009). High field MRI in the diagnosis of multiple sclerosis: high field-high yield? Neuroradiology, 2009; Vol.51, No.5, (March 2009), pp. 279-292.

Wattjes, MP.; Harzheim, M.; Lutterbey, GG.; Hojati, F.; Simon, B.; Schmidt, S.; Schild, HH. \& Barkhof, F. (2008). Does high field MRI allow an earlier diagnosis of multiple sclerosis? Journal of Neurology, Vol.255, No.8, (August 2008), pp. 1159-1163.

Werring, DJ.; Clark, CA.; Barker, GJ.; Thompson, AJ. \& Miller, DH. (1999). Diffusion tensor imaging of lesions and normal-appearing white matter in multiple sclerosis. Neurology, Vol.52, No.8, (May 1999), pp. 1626-1632.

White, AT.; Lee, JN.; Light, AR. \& Light, KC. (2009). Brain activation in multiple sclerosis: a BOLD fMRI study of the effects of fatiguing hand exercise. Multiple Sclerosis, Vol.15, No.5, (May 2009), pp. 580-586.

Wingerchuk, DM.; Lennon, VA.; Lucchinetti, CF.; Pittock, SJ. \& Weinshenker, BG. (2007). The spectrum of neuromyelitis optica. Lancet Neurology, Vol.6, No.9, (September 2007), pp. 805-815.

Young, IR.; Hall, AS.; Pallis, CA.; Legg, NJ.; Bydder, GM. \& Steiner, RE. (1981). Nuclear magnetic resonance imaging of the brain in multiple sclerosis. Lancet, 1981; Vol.2, No.8255, (November 1981), pp. 1063-1066.

Yousry, TA.; Major, EO.; Ryschkewitsch, C.; Fahle, G.; Fischer, S.; Hou, J.; Curfman, B.; Miszkiel, K.; Mueller-Lenke,. N.; Sanchez, E.; Barkhof, F.; Radue, EW.; Jäger, HR. \& Clifford, DB. (2006). Evaluation of patients treated with natalizumab for progressive multifocal leukoencephalopathy. New England Journal of Medicine, Vol.354, No.9, (March 2006), pp. 924-933.

Zajicek, JP.; Scolding, NJ.; Foster, O.; Rovaris, M.; Evanson, J.; Moseley, IF.; Scadding, JW.; Thompson, EJ.; Chamoun, V.; Miller, DH.; McDonald, WI. \& Mitchell, D. (1999). Central nervous system sarcoidosis--diagnosis and management. QJM: monthly journal of the Association of Physicians, Vol.92, No.2, (February 1999), pp. 103-117.

Zivadinov, R. \& Cox, JL. (2007). Neuroimaging in multiple sclerosis. International Review of Neurobiology, Vol.79, (May 2007), pp. 449-474

Zivadinov, R. \& Leist, TP. (2005). Clinical-magnetic resonance imaging correlations in multiple sclerosis. Journal of Neuroimaging, Vol.15, Suppl.4, pp. 10S-21S.

Zivadinov, R.; Reder, AT.; Filippi, M.; Minagar, A.; Stüve, O.; Lassmann, H.; Racke, MK.; Dwyer, MG.; Frohman EM. \& Khan, O. Mechanisms of action of disease-modifying agents and brain volume changes in multiple sclerosis. Neurology, Vol.71, No.2, (July 2008), pp. 136-144. 


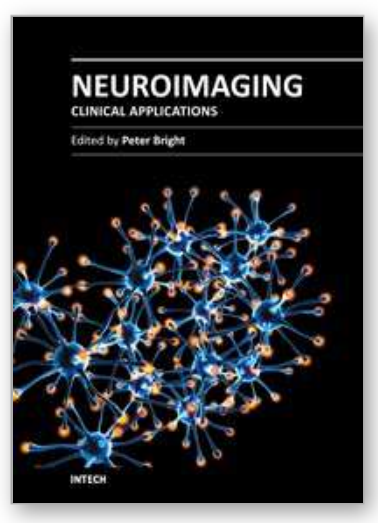

\author{
Neuroimaging - Clinical Applications \\ Edited by Prof. Peter Bright
}

ISBN 978-953-51-0200-7

Hard cover, 576 pages

Publisher InTech

Published online 09, March, 2012

Published in print edition March, 2012

Modern neuroimaging tools allow unprecedented opportunities for understanding brain neuroanatomy and function in health and disease. Each available technique carries with it a particular balance of strengths and limitations, such that converging evidence based on multiple methods provides the most powerful approach for advancing our knowledge in the fields of clinical and cognitive neuroscience. The scope of this book is not to provide a comprehensive overview of methods and their clinical applications but to provide a "snapshot" of current approaches using well established and newly emerging techniques.

\title{
How to reference
}

In order to correctly reference this scholarly work, feel free to copy and paste the following:

Elisabeth Andreadou (2012). Neuroimaging in Multiple Sclerosis, Neuroimaging - Clinical Applications, Prof. Peter Bright (Ed.), ISBN: 978-953-51-0200-7, InTech, Available from:

http://www.intechopen.com/books/neuroimaging-clinical-applications/neuroimaging-in-multiple-sclerosis

\section{INTECH}

open science | open minds

\section{InTech Europe}

University Campus STeP Ri

Slavka Krautzeka 83/A

51000 Rijeka, Croatia

Phone: +385 (51) 770447

Fax: +385 (51) 686166

www.intechopen.com

\section{InTech China}

Unit 405, Office Block, Hotel Equatorial Shanghai

No.65, Yan An Road (West), Shanghai, 200040, China

中国上海市延安西路65号上海国际贵都大饭店办公楼 405 单元

Phone: +86-21-62489820

Fax: $+86-21-62489821$ 
(C) 2012 The Author(s). Licensee IntechOpen. This is an open access article distributed under the terms of the Creative Commons Attribution 3.0 License, which permits unrestricted use, distribution, and reproduction in any medium, provided the original work is properly cited. 